\title{
Palaeoecology of the Upper Tournaisian (Mississippian) crinoidal limestones from South Belgium
}

\author{
LAURENT DEBOUT \& JULIEN DENAYER*
}

Evolution \& Diversity Dynamics Lab, Geology UR, University of Liège, Allée du Six-Août B18, Sart Tilman, 4000 Liège, Belgium; laurent.debout@alumni.ulg.ac.be,julien.denayer@uliege.be.

*corresponding author.

\begin{abstract}
The Tournaisian stage (Lower Mississippian) is known as the golden age of crinoids. In S Belgium, Upper Tournaisian crinoidal limestones, locally called "Petit Granit", are known in the Condroz area (Ourthe Formation) and in the Soignies area (Soignies Member) where tens of quarries expose the crinoidal facies. An isopach map shows that the Ourthe Formation thins northward and westward, probably because of synsedimentary block faulting. Despite its apparent monotony, five crinoidal and peloidal microfacies are identified throughout the formation, and the size and preservation of the crinoid columnals vary vertically and laterally. The encrinite deposited as amalgamated tempestites that accumulated under fair-weather wave base. An estimation of the carbonate production rate was calculated and a value of c. $1200 \mathrm{~cm}^{3} / \mathrm{m}^{2}$.y is proposed for the Ourthe Fm. The density in individuals was lower in the Hainaut area possibly due to its deeper situation. The analysis of disarticulated crinoid columnals reveals that the crinoidal meadows were diverse with several taxa following a vertical tiering model to maximise the capture of particles from the water column. Beside the crinoids, the fauna was dominated by suspension feeders (brachiopods, bryozoans, tabulate and rugose corals) adapted to a weakly-agitated environment and a relatively soft ground. Rare nektonic and benthic macrophages (holocephalan chondrychthians, actinoceratoid cephalopods, palaechinids, and trilobites) show that the ecosystem was relatively complex despite a simple appearance.
\end{abstract}

KEYWORDS: carbonate, Carboniferous, Crinoidea, Echinoderm, parataxonomy, Petit Granit, productivity.

\section{Introduction}

The Mississippian (Lower Carboniferous) and particularly the Tournaisian is known as the golden age of crinoids (Kammer \& Ausich, 2006). In suitable settings, the crinoids lived in vast meadows that formed the carbonate rock through the accumulation of their skeletal elements and named regional encrinites (sensu Ausich, 1997). Tournaisian encrinites are wide developed all over the world with renown examples from Ireland (Waters \& Sevastopulo, 1984), N America (Ausich, 1999a,b), S China (Chen \& Yao, 1993), Iran (Webster et al., 2003), etc. The expansion of crinoids during the Tournaisian is interpreted as a recovery phase following the Late Devonian extinctions, as it induced a rapid re-colonisation of the ecological niches by crinoids and then a rapid evolution (McGhee, 1996). The autoecology of crinoids is relatively well understood (Ausich \& Bottjer, 1982, 2007; Ausich \& Simms, 1999; Ausich et al., 1999a) in contrast to their synecology (i.e. interactions with the environment and with other organisms) despite their ability to shape their environment.

In South Belgium, Tournaisian encrinites are abundant and locally called "Petit Granit" where quarried as cut stones for building and carving purposes. Several units were - and still are - intensively quarried for these purposes: the Hastière Formation (Fm), Landelies Fm, Ourthe Fm, Flémalle Membre (Mbr) and Soignies Mbr. The most valuable and renowned are the encrinites of the Ourthe Fm in the Condroz area (central Belgium) and Soignies Mbr of the Ecaussinnes Fm in the Hainaut area (W Belgium) (Poty \& Chevalier, 2004). Although the "Petit Granit" is relatively well known from historical and extractive points of view (e.g. Groessens, 1981, 1994), studies concerning the palaeoenvironment and the fossil assemblage of these crinoidal meadows are scarce (Hardy, 1973; Hibo, 1994).

The crinoid diversity is almost unknown in the Ourthe Fm and in the Soignies Mbr and based on old-fashion fauna list, e.g. de Koninck \& Le Hon (1854) who cited only Poteriocrinus crassus and Platicrinus laevis - now Poteriocrinites crassus and Platycrinites laevis, based on very few specimens. Because modern taxonomy of crinoids is based on the calyx, it is not applicable to the Belgian encrinites as complete calyxes are extremely rare. However, the taxonomic diversity can be approached by the parataxonomy of Moore \& Jeffords (1968) based on stem columnal elements as it was demonstrated by Głuchowski (2002) or Gorzelak et al. (2013).

Similarly, other organisms have been already identified from the Belgian encrinites: brachiopods (de Koninck, 1887; Demanet, 1934), conodonts (Groessens, 1971, 1973, 1975), foraminifers (Conil et al., 1991; Poty et al., 2006) and corals (Tourneur et al., 1989; Poty, 1989; Denayer et al., 2011).

\section{Settings}

During the Tournaisian, S Belgium was located on the southern margin of Laurussia within the intertropical area (Golonka, 2007). The Namur-Dinant Basin was a vast shelf fragmented by a differential subsidence in six sedimentation areas (Poty, 2016). The Namur sedimentation area (NSA) located directly south of the Brabant Massif and where the depth increased from north to south; the Condroz sedimentation area (CSA), which is the southern extension of the NSA and presents proximal marine facies; the Dinant sedimentation area (DSA) that is relatively deeper and influenced by the Waulsortian complex; the highly subsiding Hainaut sedimentation area (HSA) recorded $>2500$ $m$ of Dinantian rocks including thick evaporitic formations; the Vesdre-Aachen sedimentation area (VASA) that is the lateral extension of the NSA; the Avesnois sedimentation area (ASA) which presents similar facies to CSA. The Figure 1 shows the location of these sedimentation areas.

In the CSA, the Upper Tournaisian is c. $140 \mathrm{~m}$-thick and comprises - from the base to the top - the Yvoir Fm (crinoidal and bioclastic wackestone to packstone with chert), the Ourthe Fm (encrinite) and the Martinrive Fm (dark fine mudstonewackestone with chert and anhydrite pseudomorphs) (Hance et al., 2001, 2006; Poty et al., 2006).

In the HSA, the crinoidal deposits reach $300 \mathrm{~m}$ in thickness due to the higher subsidence (Poty, 2016). The Lalaing Fm (crinoidal wackestone and dolomite) at the base of the Upper Tournaisian, overlaid with the Ecaussinnes Fm, comprises the Perlonjour Mbr (argillaceous wackestone) and Soignies Mbr (crinoidal packstone). The upper part comprises the Malon-Fontaine Fm divided in the Thiarmont Mbr (argillaceous wackestone) and Cognebeau Mbr (argillaceous wackestone with cherts) (Groessens, 1978; Doremus \& Hennebert, 1995; Poty et al., 2001).

In the VASA, the proximal equivalent of the Ourthe Fm is the Hastenrath Mbr (Poty, 2016), a 10 m-thick unit of oolithic grainstone (Vaughanites Oolithe of Kasig, 1980) including crinoidal grainstone at the base (Amler \& Herbig, 2006).

In the NSA, the equivalent of the Hastenrath oolithic Mbr and Ourthe crinoidal Fm are dolomitised (Engihoul Fm equivalent to the Namur Dolostones Group) and reduced in thickness to c. $10 \mathrm{~m}$. It is also partly dolomitised in the ASA where the Ourthe Fm passes to the lower part of the Grives Limestone (Hance et al., 2001).

In the DSA, the Ourthe Fm passes laterally to the Waulsortian complex (Waulsort mudmounds and crinoidal wackestone of the Bayard and Leffe formations). 


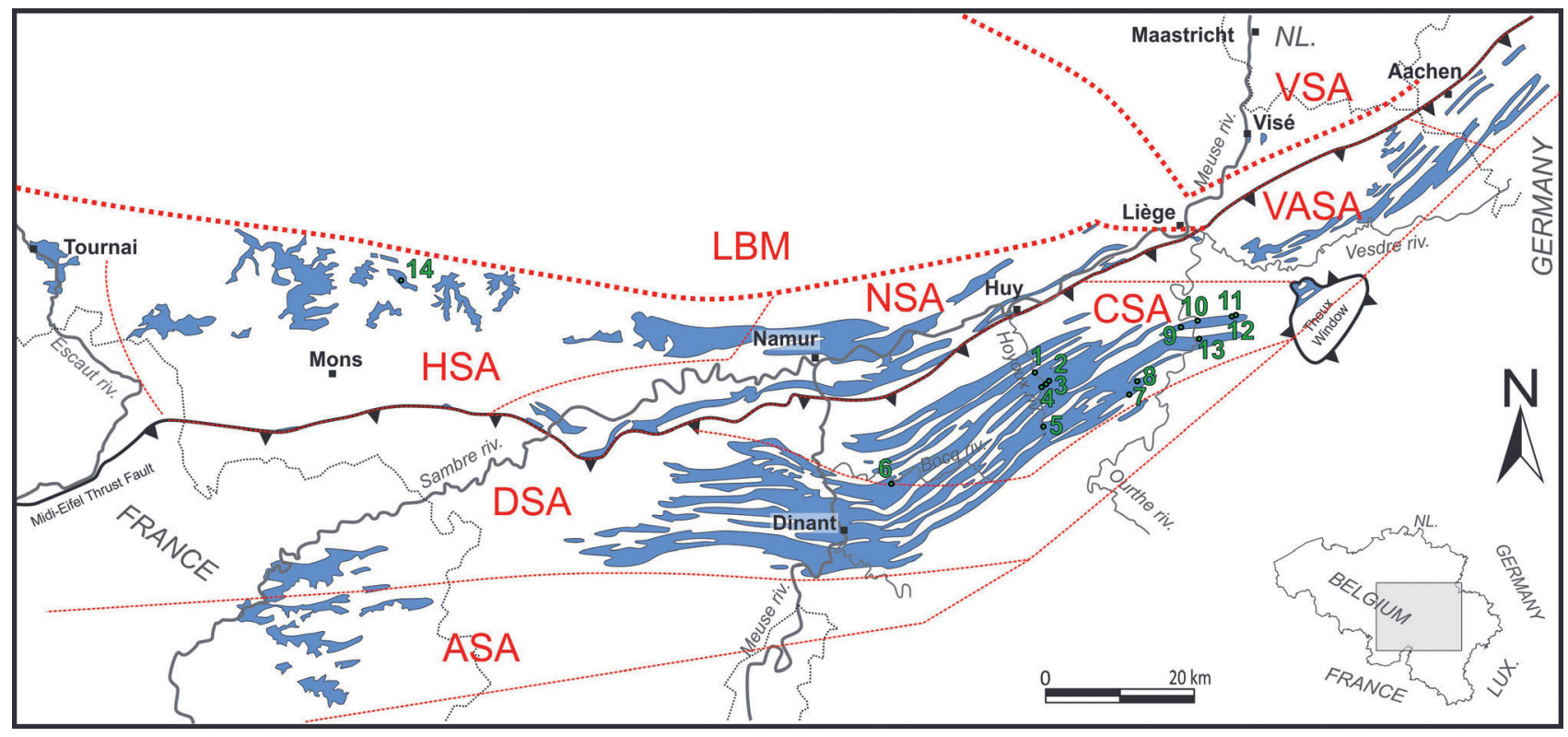

Figure 1. Schematic geological map of S Belgium and adjacent areas. Lower Carboniferous strata (blue shades), position of the studied sections (green dots) and boundaries of the sedimentation areas (red striped line). Legend: 1: Royseux quarry, 2: Les Ornais quarry (Pont-de-Bonne), 3: Herboth quarry (Pont-de-Bonne), 4: Vivaqua quarry (Pont-de-Bonne), 5: Mercier quarry (Petit-Avin), 6: Trou des chats quarry (Durnal), 7: Jenneret quarry; 8: Gripierres quarry (Ouffet), 9: Moris quarry (Mont), 10: La Préalle quarry (Chanxhe), 11: Rondia quarry (Sprimont), 12: Sprimont quarry; 13: La Belle Roche quarry (Comblain-au-Pont), 14: Gauthier Wincqz quarry (Soignies).

As demonstrated by Hance et al. (2001), the Dinantian deposits of the Namur-Dinant Basin are arranged in third-order sequences (Fig. 2). Moreover, the Tournaisian units display a lower order cyclicity, i.e. precession cycles of c. 20 kyr (Poty, 2016). However, the sedimentary context that prevailed during the deposition of the Ourthe and Soignies encrinites hampered a clear record of these cycles.

The Ourthe Fm and its equivalents correspond to the highstand system tract (HST) of the third order sequence 3 of Hance et al. (2001, emended by Poty, 2016). The dolomitised upper beds of the formation possibly correspond to the falling-stage system tract, but its vertical extension and lateral continuity are too variable to demonstrate this assumption. Nevertheless, the Ourthe Fm is capped by a subaerial erosive (emersion) surface, and the correlative conformity at the top of the Soignies Fm is interpreted as the sequence boundary. The overlying sediments correspond to the lowstand and transgressive system tracts of the following sequence 4A of Poty (2016) (Fig. 2). The Ourthe Fm and Soignies
Mbr both yield an impoverished rugose coral fauna including Caninia cornucopiae, Caninophyllum patulum, Cyathaxonia cornu, Siphonophyllia cylindrica, Sychnoelasma omaliusi and Zaphrentites cf. crassus, that indicates the RC $3 \beta$ zone of Poty et al. (2006). Note that in the proximal equivalents (Hastenrath $\mathrm{Mbr}$ ), the coral fauna is more diverse with Keyserlingophyllum obliquum, Uralinia cf. multiplex, and the tabulate Vaughanites flabelliformis (Poty, 2016). Similarly the foraminifers are poorly diverse, but previous studies (Conil, 1973; Conil \& Lys, 1977) noted some endothyrids and tournayellids indicating the MFZ5 (Poty et al., 2006). Conodonts are more abundant in these facies, and Polygnatus communis carina and Dollymae bouckaerti, guides of the eponymous zones, are rather common in the Ourthe Fm (Groessens 1973, 1975) and Soignies Mbr (Groessens, 1971, 1975) and allow their correlation.

Although relatively monotonous in lithology, the Ourthe Fm (i.e. "Petit Granit de l'Ourthe") was divided into six to eight beds and sets of beds either separated by stylolites or true depositional

\begin{tabular}{|c|c|c|c|c|c|c|c|c|c|c|c|}
\hline \multicolumn{6}{|c|}{ Lithostratigraphy } & \multirow{2}{*}{$\begin{array}{l}3^{\text {rd }} \\
\text { ord. } \\
\text { seq. }\end{array}$} & \multirow{2}{*}{ 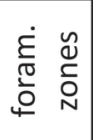 } & \multirow{2}{*}{$\begin{array}{ll}\overline{0} \\
\overline{0} \\
\overline{0} \\
\end{array}$} & \multirow{2}{*}{ 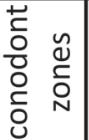 } & \multirow{2}{*}{\multicolumn{2}{|c|}{ 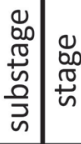 }} \\
\hline HSA & VASA & NSA & CSA & DSA & ASA & & & & & & \\
\hline Cognebau & Bärenstein & Engihoul & Martinrive & & Grives Dlst & $4 \mathrm{~A}$ & MFZ6 & & anch. & & \\
\hline Thiarmont & & & 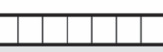 & & & & & & & . 단 & \\
\hline Soignies & Hastenrath & & Ourthe & & Grives Lmst & & MFZ5 & $c \underline{\beta}$ & ") & פ̄ & $\frac{\pi}{2}$ \\
\hline Perlonjour & & Engihoul & Yvoir & Bay- & & 3 & & $3 a$ & & & \\
\hline Lalaing & & & & & & 3 & MFZ4 & & $\stackrel{0}{=}$ & & \\
\hline Arquennes & & & Maurenne & Maurenne & & & MFZ3 & $\mathrm{R}$ & $\frac{8}{8}$ & : & \\
\hline 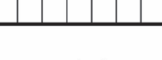 & I andelies & & 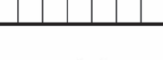 & 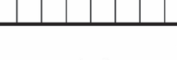 & & 2 & & C & 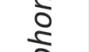 & 营 & \\
\hline Landelies & (dolostone) & Engihoul & Landelies & Landelies & Landelies & 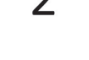 & MFZ2 & 2 & $i^{2}$ & 10 & \\
\hline
\end{tabular}

Figure 2. Chrono-; bio- and lithostratigraphy of a part of the Tournaisian in the Namur-Dinant Basin. Grey area corresponds to the studied interval, stripped area figures depositional hiatuses. Adapted from Poty et al. $(2001,2006)$ and Poty $(2016)$. Abbreviations: ASA: South Avesnois sedimentation area, CSA: Condroz sedimentation area, DSA: Dinant sedimentation area, HSA: Hainaut sedimentation area, NSA: Namur sedimentation area, VASA: Vesdre-Aachen sedimentation area, $3^{\text {rd }}$ ord. seq.: third-order sequences of Hance et al. (2001) emend. Poty (2016), anch.: anchoralis, Dlst: dolostone, foram.: foraminiferan, Lmst: limestone. 
discontinuities (Libert, 1911; Groessens, 1978). Names were given by quarrymen to each set, commonly expressing a character of the rock (colour, hardness, purity ...). The base of the formation is named "Grisou" beds, a c. 6 m-thick light-coloured, hard, often dolomitised unit of little interest for quarrymen (Groessens, 1978; Hardy, 1973). The "Gris-bec" presents a whitish shade unpleasant once polished and is overlaid with the "Gros banc", an 8-10 m-thick massive unit intensively quarried. It is generally overlaid with the "Bancs minces", which are a succession of metre-thick beds and then with the "Dure croûte", a decimetrethick slightly silicified bed that can be correlated from quarry to quarry in the entire CSA. In some place of the CSA, it is overlaid with the "Bancs de 6 pieds", which groups a variable number of thin beds. Above, lay the "Bancs bleus" and the "Bancs noirs" both presenting a darker colour making them very valuable as ornamental stone. The "Banc de désserre" - also called "Floribanc" - ends this succession with metre-thick beds below the Martinrive Fm.
Similarly, the Soignies Mbr of the Ecaussinnes Fm (i.e. "Petit Granit de Soignies") was divided in about 20 beds sets which are, from the base to the top (Groessens, 1978; Hibo, 1994), a set of sub-metric beds overlaid with the $6.5 \mathrm{~m}$-thick crinoidal grainstone of the "Gros banc", the "Noir banc" and the "Bon 2 mètres". The "Litée à dalles", an argillaceous limestone with calcite geodes and the "Pas de Loup", a bioclastic limestone yielding large Asteractinella expansa sponges are then overlaid with a 4 m-thick set of thin beds comprised of (light) blueish packstone. Above the Soignies Mbr, the sedimentation changes to an alternation of thinly-bedded, fine-grained argillaceous limestone beds and marlstone interbeds forming the Thiarmont Mbr of the Malon-Fontaine Fm ("Raches" of the quarrymen, Poty et al., 2001). These facies are rather fossiliferous (crinoids, rugose corals, brachiopods, trilobites, etc.), but the crinoidal content is lower than in the Soignies Mbr. However, the boundary between the two members is transitional with progressive intercalation of argillaceous interbeds of increasing thickness upwards. The
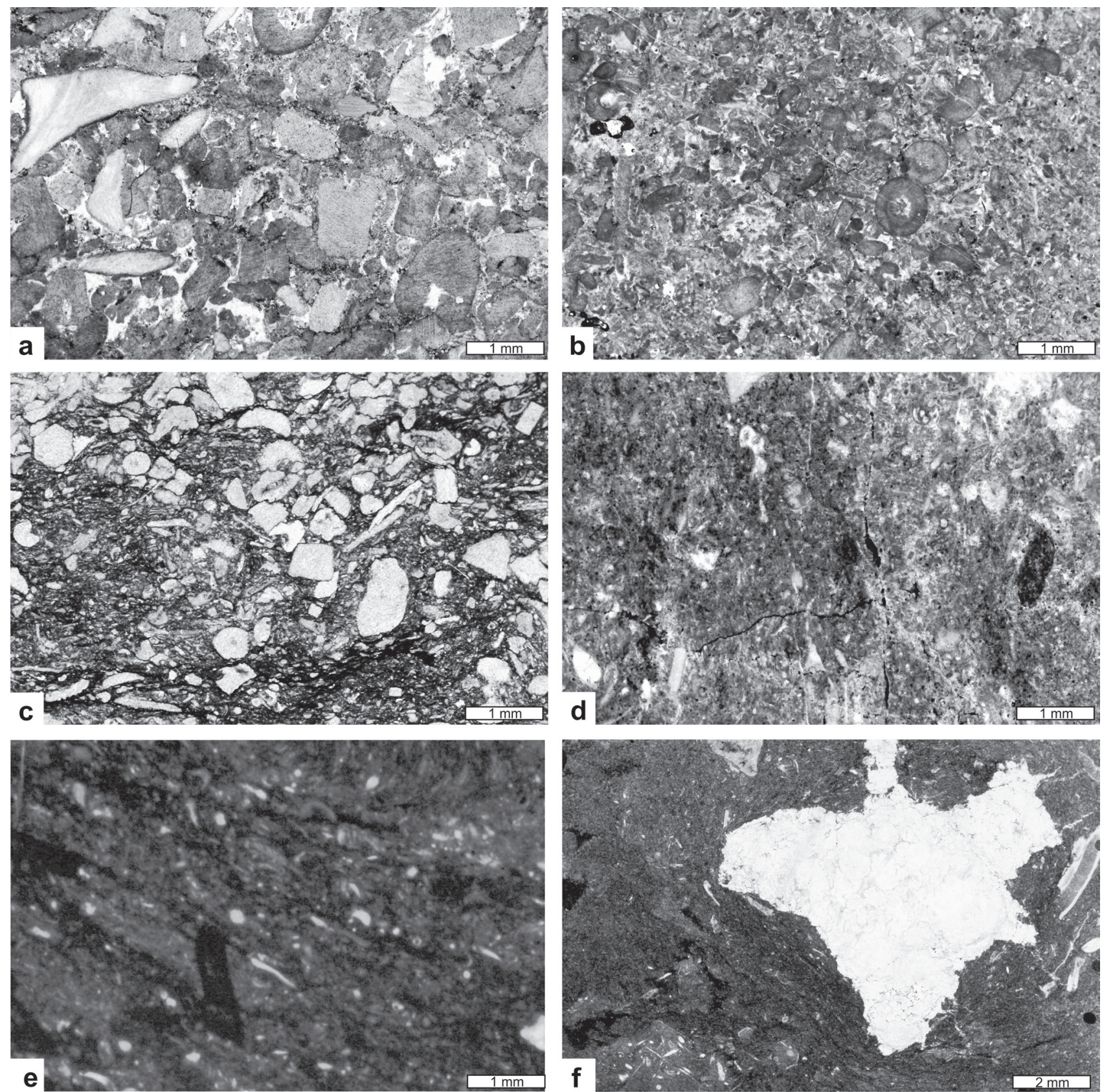

Figure 3. Microfacies from the Ourthe Fm and Soignies Mbr. a: MF1 crinoidal grainstone-rudstone (Ourthe Fm, Royseux quarry, RIX-6), dominated by crinoids and some brachiopods; b: MF2, crinoidal and peloidal grainstone (Ourthe Fm, Dorinne quarry, Dor-5); c: MF3, crinoidal packstone (Soignies Mbr, Gauthier-Wincqz quarry, GW-39) with fragments of crinoids, brachiopods and bryozoans; d: MF4, bioclastic packstone-wackestone (Ourthe Fm, Royseux quarry, RIX-25) with rare brachiopod fragments, darker areas result of bioturbation; e: MF5, bioclastic mudstone (Ourthe Fm, Grispierre quarry, Ouffet, Gri-21); f: calcite pseudomorph after anhydrite in a wackestone (base of the Martinrive Fm, La Préalle quarry, Pré-1). 


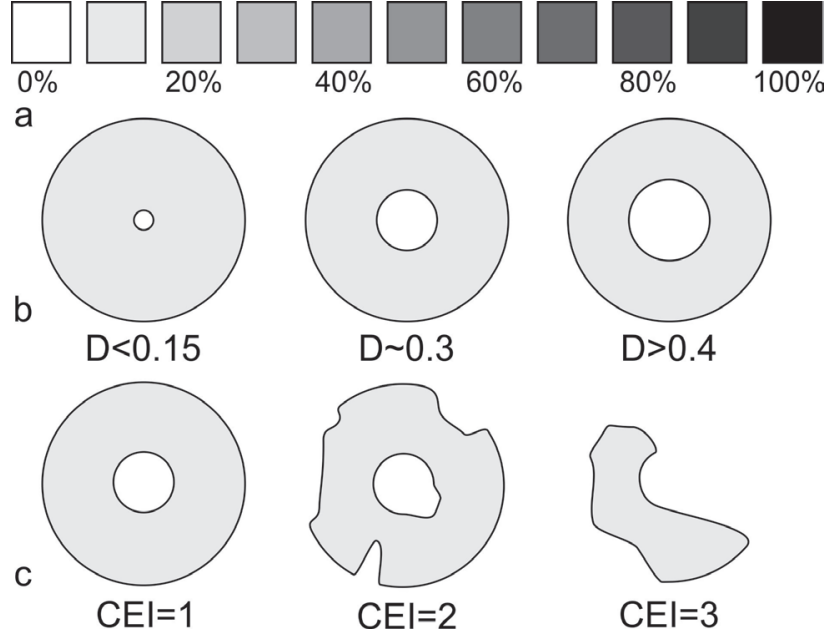

Figure 4. Criteria used to characterise the crinoidal lithologies; a: shade scale expressed in percent of black used to characterise the colour of the rock (see text); b: types of columnal based on the lumen diameter on columnal diameter ratio; c: Crinoid Erosion Index of the columnal, qualifying the erosion state of the columnal regardless of the origin of the erosion.

sequence boundary is a conformity with no trace of emersion, probably because it was deposited in deeper settings.

In both sedimentation areas, a thin argillaceous bed is present that is considered a weathered K-bentonite horizon (Anceau, 1993) that is partly amalgamated into the limestone by bioturbation. In the CSA, it is located between the "Bancs minces" and the "Bancs bleus" of the Ourthe Fm and between the "Dure croûte" and the "Bon 70" in the Soignies Mbr of the HSA. Historically they were called "Dure croûte" in the Ourthe Fm and "Délit à la terre" in the Soignies Mbr, but despite their similar mineralogy, their correlation could not be done with certainty (Anceau, personal communication, Dec. 2017). However, as they occurred in both localities some metres below the sequence boundary, it seems logical that they recorded the same, possibly isochronous, phenomenon.

\section{Materials and methods}

Thirteen quarries exposing the Ourthe Fm have been studied in the CSA (see Fig. 1) as well as one quarry exposing the Soignies Mbr in the HSA. For each quarry, the section was logged, and two or three samples were collected from each bed for thinsectioning (30x45 $\mathrm{mm}$ and $45 \times 60 \mathrm{~mm}$ oriented thin sections). Additional samples were collected for macrofossils. All material was deposited in the collections of animal palaeontology of the Liège University.

Every 306 lithological sample was described following five criteria: the microfacies, the colour of the rock, the average diameter of crinoid columnals, the lumen to diameter ratio of the crinoid columnals and their erosion degree. As discussed below, it was not possible to distinguish crinoid columnals from elements of blastozoans and rhombiferans. However, their rarity in the Belgian Carboniferous pleads for anecdotal occurrences (Marcuda, 1967).

\subsection{Microfacies}

MF1 (Fig. 3a) is a crinoidal grainstone made of $70-80 \%$ of crinoid fragments along with dissociated brachiopod shells, fragmented ramose bryozoans, palaechinid spines, small rugose and tabulate corals, often fragmented. Intergranular and intragranular porosities are rare and filled by sparite. There is no preferential direction and the sorting is relatively good (elements usually $>0.6 \mathrm{~mm}$ ). Bioturbation is frequent.

MF2 (Fig. 3b) is a crinoidal and peloidal grainstone made of $70-80 \%$ of crinoid debris and (infra-)millimetric peloids. Intergranular porosity is filled by sparite. Palaechinid spines, fragmented brachiopod shells, tabulate corals and bryozoans are common. There is no preferential direction and the sorting is rather poor. Bioturbation is frequent.

MF3 (Fig. 3c) is a crinoidal packstone comprised of a fine micritic matrix $(40-50 \%)$ usually rich in organic matter. Some well-preserved columnals (10-15\%) and palaechinid spines, fragmented brachiopod shells, ostracods, small rugose and tabulate corals are common, in laterally limited floatstone pockets (bioturbation?). There is no preferential direction, no laminations or intergranular porosity and the sorting is poor.

MF4 (Fig. 3d) is a bioclastic wackestone comprised of a micritic matrix $(50-60 \%)$ relatively rich in organic matter. The dominant allochems are small crinoid and palaechinid fragments $(<1 \mathrm{~mm})$, fragmented brachiopod shells, ostracods, bryozoan, plurilocular foraminifers and small solitary rugose corals. There is no preferential direction but the sorting of the allochems is relatively good.

MF5 (Fig. 3e) is a poorly bioclastic mudstone with rare fossils (small crinoid fragments, ostracods, plurilocular foraminifers, gastropods). There is no preferential direction or lamination and few bioturbations. This facies is interpreted as representing the settling of fine particles in a confined and probably restricted environment as suggested by the numerous anhydrite pseudomorphs (Fig. 3f). The marine fauna however suggest an occasional open marine influence.

\subsection{Colour}

The colour of the samples was estimated by comparison to a standard greyscale expressed in percent of black (Fig. 4a) on a wet freshly sawn rock surface under an artificial white light presenting a constant incidence and intensity. Hence it is a semi-quantitative, mostly descriptive data. The dark colour reflects the organic content but also the fine granulometry, but dolomitisation and the intensity of bioturbation also have an effect on the resulting colour of the limestone. It is poorly useful for palaeoenvironmental interpretation as no vertical tendency seems to appear but is locally an additional character to identify the beds and sets of beds.

\subsection{Crinoid columnal diameter}

Minimum, average and maximum value of the diameter of crinoid columnals were measured on each thin section (smallest diameter where columnals are obliquely cut), and presented as a solid curve and envelope.

\subsection{Crinoid morphology}

The ratio (D) of the lumen diameter on the columnal diameter measured on thin section (smallest diameter where columnals are obliquely cut) has a systematic meaning and serves as a diversity descriptor for each sample. Following Moore \& Jeffords' (1968) parataxonomy of crinoids (see 5.3.), the ratio is in three categories (Fig. $4 b$ ): columnals with a small lumen with $\mathrm{D}<0.15$, and large lumen with $\mathrm{D}>0.4$, and the intermediate categories between these two values. Note that the ratio was not measured on elliptical columnals nor on columnals with non-circular lumen (pentagonal and pentalobate) simply because of their rarity in thin section.

\subsection{Crinoid erosion index}

The columnal erosion index (CEI) is a qualitative descriptor of the average state of erosion of the crinoid columnals (Fig. 4c). CEI 1 corresponds to intact, unbroken columnals, CEI 3 corresponds to non-recognisable elements. CE2 is an intermediate category. The CEI is a good indicator of taphonomic effects with highly eroded elements suggesting higher fragmentation and abrasion that witness a longer transportation and/or reworking and/or a longer exposure on the sea floor (see discussion in 5.1.). However the CEI does not reflect the type of erosion, i.e. hydrodynamic, dissolution or bioerosion.

\section{Description of the key sections}

Only five sections out of the thirteen studied are presented here as the most complete and the most representative for each area. In addition, the Soignies section is described for comparison. 


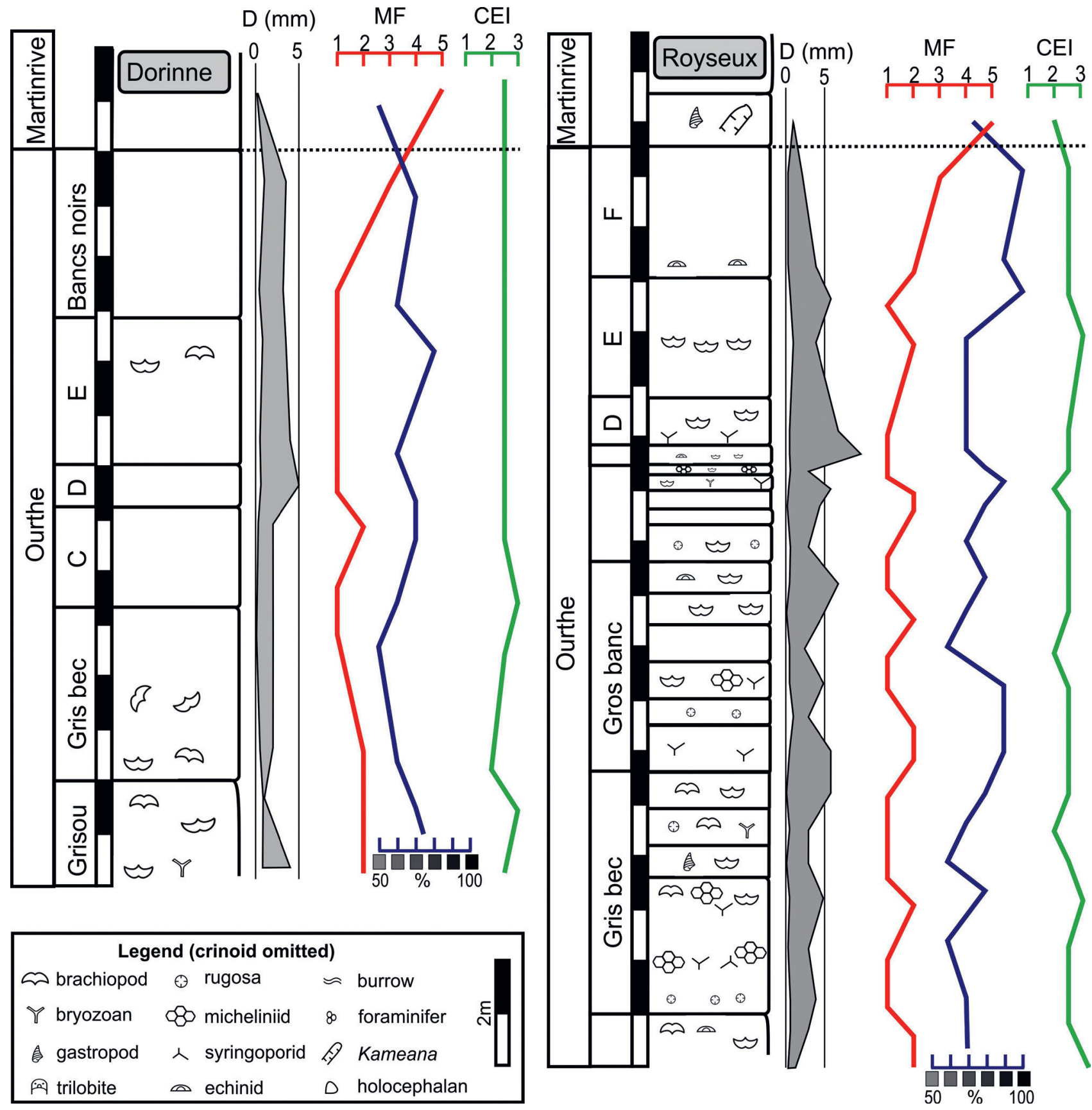

Figure 5. Schematic profiles of the Ourthe Fm in the Royseux disused quarry and Dorrine quarry. Legend: MF: microfacies (see main text), CEI: crinoid erosion index, D (mm): average crinoid columnal diameter in mm. C: "Gros Banc", D: "Banc de Terre" and "Bancs minces", E: "Bancs Bleus", F: "Bancs noirs".

\subsection{Royseux disused quarry (Figs 5, 6)}

This disused quarry is situated on the right bank of the Hoyoux River in front of the Royseux Castle in the proximal part of the CSA. The Ourthe Fm is $<20$ m-thick, and the very base of the "Grisou" is not exposed. The microfacies alternates between a peloidal and crinoidal grainstone MF2, and a crinoidal grainstone MF1 up to the top of the unit where the crinoidal packstone MF3 dominates. The boundary with the Martinrive Fm - characterised by a bioclastic mudstone MF5 - is sharp. The macrofauna is rather diverse at the base of the "Gris bec" and in the "Bancs minces" with many brachiopods, micheliniid tabulate corals in flat colonies up to $15 \mathrm{~cm}$-large, small solitary rugose corals (Cyathaxonia cornu, Zaphrentites cf. crassus) and straparollid gastropods. The columnal diameter varies between 0.2 and $10 \mathrm{~mm}$ with maxima locally observed at the top of the "Gros banc", and at the base of the "Bancs noirs". The colour varies between $60 \%$ and $100 \%$ black, the darkest colours characterising in the "Bancs noirs". The CEI is relatively high throughout the formation suggesting an intense and continuous reworking of the material. Some beds display undulated boundaries (Fig. 6c) corresponding to hummocky cross-stratifications. The upper beds of the formation are intensively bioturbated.

\section{2. "Trou des Chats" quarry at Dorinne (Fig. 5)}

This quarry, in part backfilled, is located between Spontin and Dorinne in the southern CSA. The Ourthe Fm is c. 15 m-thick, but the base of the "Grisou" is not exposed. The MF1-2 dominate up to the top of the formation where a crinoidal packstone MF3 is observed. The columnal diameter varies from 0.2 to $5 \mathrm{~mm}$ with maxima in the middle of the "Grisou", the middle of the "Bancs minces" and in the top of the "Bancs noirs". The CEI fluctuates between the "Grisou" and the "Gros banc" and then stabilises up to the top of the formation. The colour is relatively light. The macrofauna is poor with few brachiopods and bryozoans.

\subsection{Jenneret quarry (Figs 6, 7)}

This active quarry is located $650 \mathrm{~m} \mathrm{SW}$ of the Jenneret village in the Néblon valley in the eastern CSA. The Ourthe Fm is $>32 \mathrm{~m}$-thick but again the "Gris bec" and the "Grisou" are discontinuously 

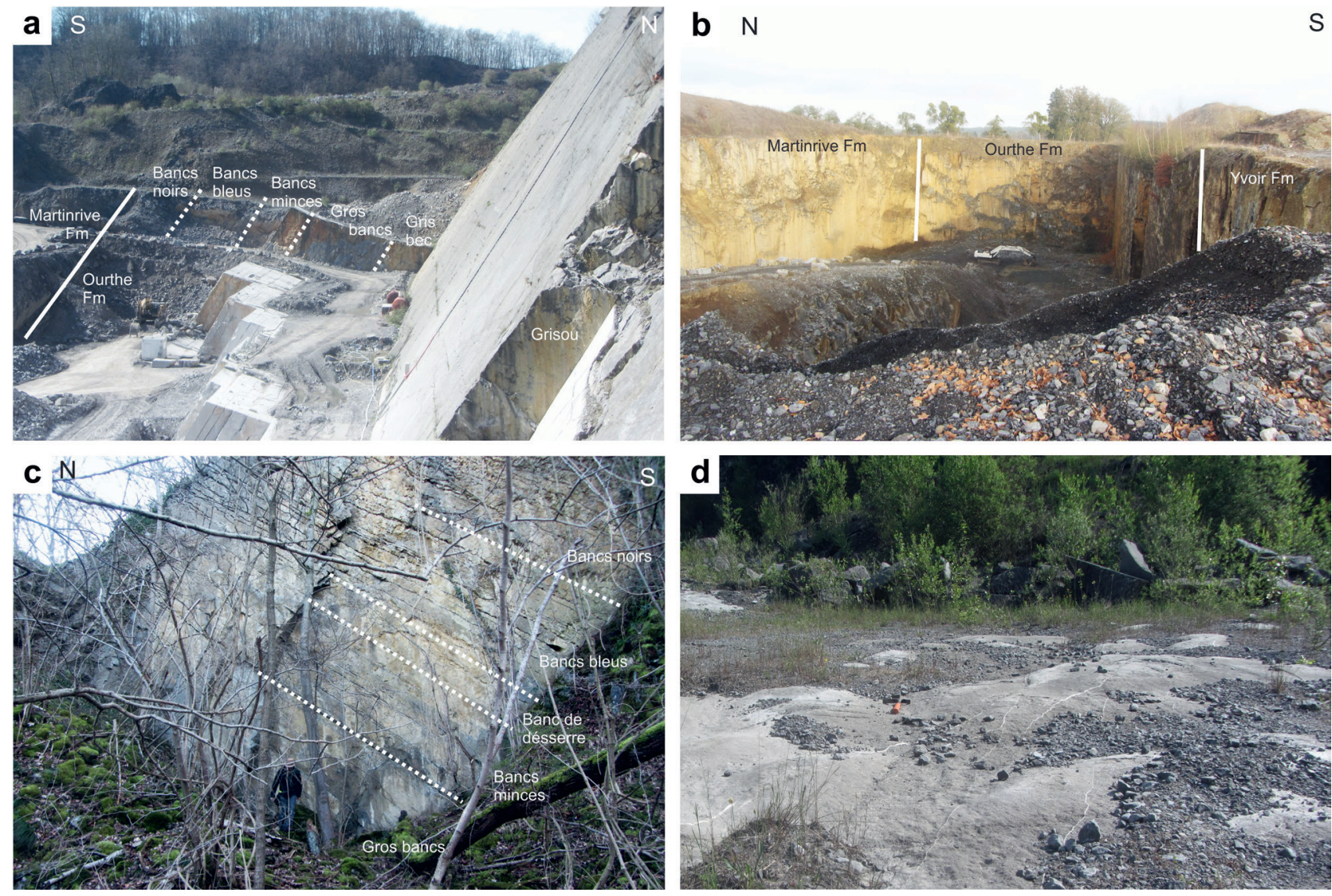

Figure 6. Field pictures of the "Petit Granit". a: view of the La Préalle quarry (Chanxhe) with denomination of the quarried beds; b: view of the Jenneret quarry showing base and top of the Ourthe Fm; c: view of the Royseux disused quarry with denomination of some beds; d: hummocky crossstratifications at the top of the "Pas de Loup" bed, Gauthier-Wincqz quarry in Soignies.

exposed. Throughout the formation, the microfacies varies from a crinoidal packstone MF3 to a peloidal and crinoidal grainstone MF2 or crinoidal grainstone MF1. The base of the Martinrive Fm comprises a crinoidal packstone MF3 progressively richer in Kameana and bryozoan up-section. The fauna is relatively diverse in all levels with crinoids, bryozoans, brachiopods and occasional palaechinid remains. Plurilocular foraminifers (endothyrids) appear in the "Bancs noirs". The uppermost part of the formation is intensively bioturbated. Columnal diameter fluctuates between 0.2 and $7 \mathrm{~mm}$ with maxima at the top of the "Gris bec", at the top of the "Gros banc", at the base of the "Bancs bleus" and at the base of the "Bancs noirs". The CEI is relatively constant throughout the formation and close to 1 . The colour is light from the "Gris bec" to the "Gros banc" and then gets darker up-section, up to the Martinrive Fm.

\subsection{Mont quarry (Fig. 7)}

This active quarry is located $1200 \mathrm{~m} \mathrm{~N}$ of the Mont village, on the western side of the Ourthe valley in the eastern CSA. The Ourthe Fm is 34 m-thick but the base of the "Grisou" is not exposed. The microfacies varies from a crinoidal grainstone MF1 to a crinoidal packstone MF3. A peloidal and crinoidal grainstone MF2 characterises the top of the "Bancs minces". The fauna is relatively poorly diverse at the base of the Ourthe Fm but it is more diverse in the "Bancs minces" and "Bancs bleus" with numerous (large) crinoid columnals, bryozoans, brachiopods and the solitary rugose coral Cyathaxonia cornu, palaechinids and gastropods are occasional. From the "Bancs noirs" upwards, the diversity decreases rapidly with disappearance of almost all macrofauna, except crinoids. The columnal diameter varies between 0.2 and $8.5 \mathrm{~mm}$ with maxima at the base of the "Gros banc", in the middle of the "Bancs minces" and in the "Bancs noirs". The CEI is stable with a minimum in the "Gros banc". The colour is relatively dark all along the formation.

\subsection{Belle-Roche quarry (Fig. 8)}

The Belle-Roche quarry is located $2500 \mathrm{~m}$ E of Comblain-au-Pont, in the Amblève valley, in the eastern CSA. The Ourthe Fm is 47 m-thick and was studied from a core drilled in 2012 and curated at the University of Liège (Belgium). The microfacies varies from a crinoidal packstone MF3 to a peloidal and crinoidal grainstone MF1-2 up to the "Bancs noirs" which is again a crinoidal packstone MF3. The base of the Martinrive Fm is a bioclastic wackestone MF4 with bryozoans and the rugose coral Cyathaxonia cornu. The diversity is relatively low (brachiopods, crinoids, Cyathaxonia cornu) up to the top of the "Gros banc". Bryozoan and palaechinids appear in the "Bancs minces" and disappear at the base of the "Bancs bleus". The columnal diameter fluctuates between 0.2 and $9 \mathrm{~mm}$ with maxima in the middle and at the top of the "Grisou", at the middle and at the top of the "Gros banc", at the top of the "Bancs minces" and at the top of the "Bancs noirs". The CEI is stable (CEI1) up to the middle of the "Bancs bleus". The colour is relatively light below the "Bancs noirs" then peaks at $100 \%$ black.

\subsection{Gauthier-Wincqz quarry at Soignies (Fig. 8)}

This active quarry is located along the N55 road in Soignies in the HSA. The Soignies Mbr is $36 \mathrm{~m}$-thick. The microfacies regularly varies from a crinoidal packstone MF3 to a crinoidal grainstone MF2 and a peloidal and crinoidal grainstone MF1 up to the top of the member where 40-60 cm-large and up to $15 \mathrm{~cm}$-high hummocky cross-stratifications occur (Fig. 6d). The fauna is relatively diverse in the basal part of the member with abundant crinoids, bryozoans, brachiopods, numerous Cyathaxonia cornu and micheliniid tabulate corals. Palaechinids and vertebrates remains are occasionally abundant in the "Grosse fine". Micheliniids disappear from the "Cul de Poupli" up to the "Pas de loup" where trilobites, gastropods, and large asterosponges occur. The upper part of the Soignies Mbr is relatively poor in macrofauna. At the base of the Thiarmont Mbr, the faunal diversity increases: crinoids, trilobites, bryozoans, productid, spiriferid, spiriferinid and strophomenid 


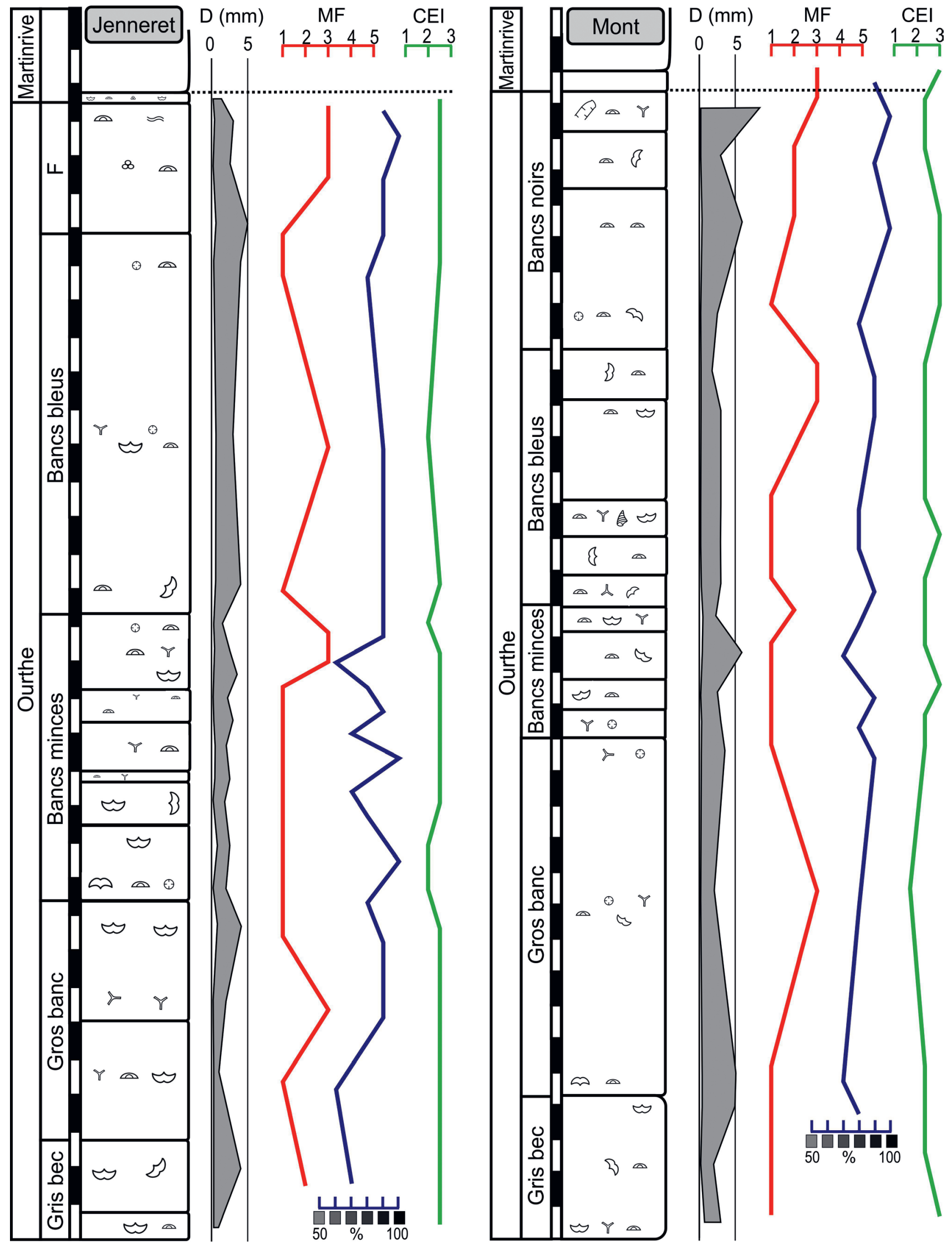

Figure 7. Schematic profiles of the Ourthe Fm in the Jenneret quarry and Mont quarry. Legend: MF: microfacies (see main text), CEI: crinoid erosion index, D (mm): average crinoid columnal diameter in $\mathrm{mm}$. See Figure 5 for legend.

brachiopods, solitary rugose corals and tabulate corals (Fig. 9) are common, vertebrate remains (holocephalan dental plates) are occasional. The columnal diameter fluctuates between 0.2 to 10 mm with maxima at the base of the "Gros dur", at the top of the "2eme belle", at the top of the "Cul de Poupli", at the top of the "Banc dit de 3 mètres", at the top of the "Mauvais 2 mètres", at the base of the "Bon 2 mètres", at the base of the "Litée à dalles" and in the middle of the "Pas de Loup". The CEI is close to 1 up to the base of the "Bon 2 mètres" and then has intermediate values up to the Thiarmont Mbr. The colour regularly varies between $60 \%$ and $100 \%$ black, the upper part of the Soignies Mbr is however darker than the lower part. 


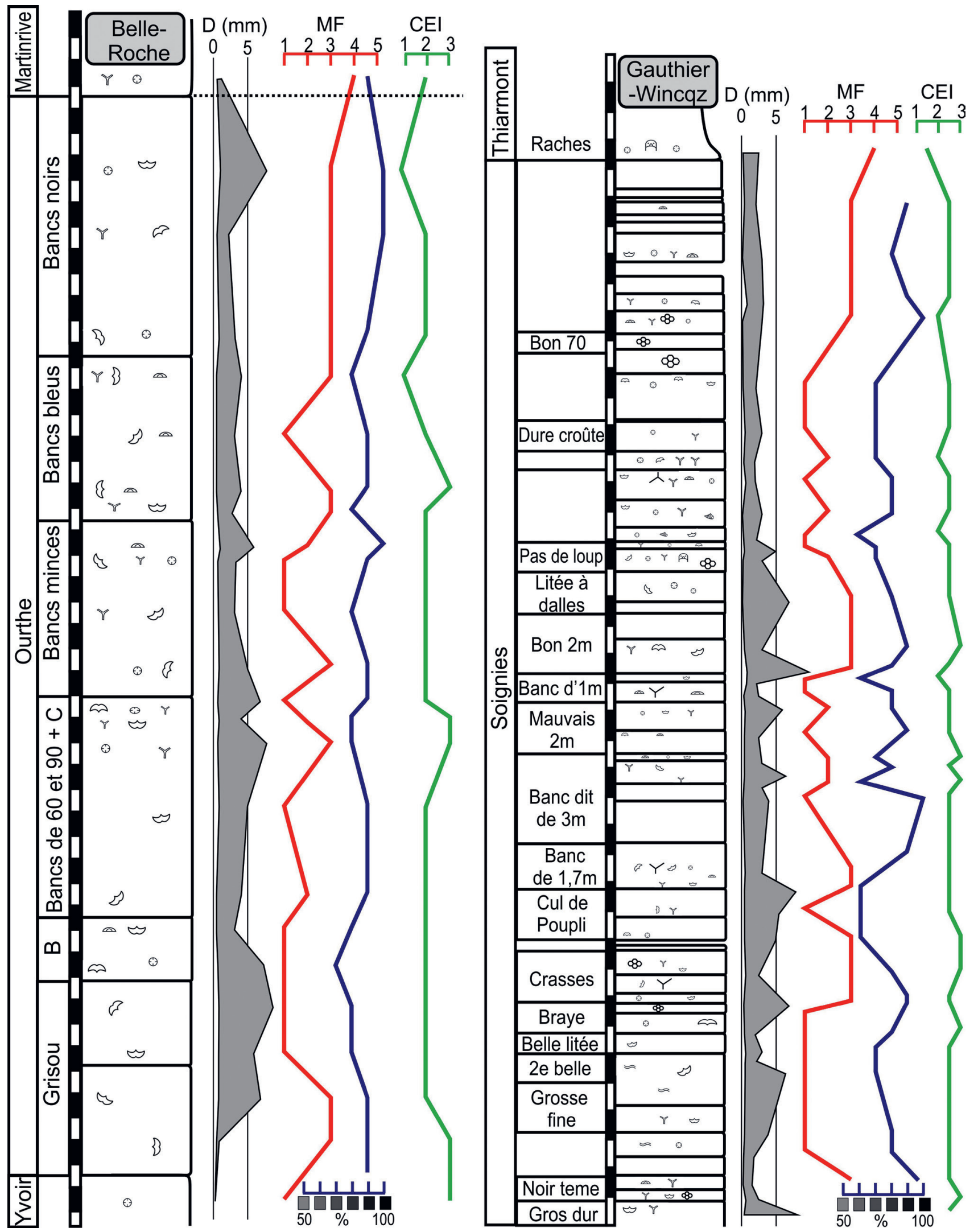

Figure 8. Schematic profiles of the Ourthe Fm in the Belle Roche quarry and of the Soignies Mbr in the Gauthier-Wincqz quarry. Legend: MF: microfacies (see main text), CEI: crinoid erosion index, D (mm): average crinoid columnal diameter in mm. B: "Gris Bec", C: “Gros Banc". See Figure 5 for legend.

\section{Results}

\subsection{Facies and depositional environment}

The grainstone microfacies MF1-2 are largely dominant (c. 70\%) in the Ourthe Fm where it is massive but reduced in thickness (e.g. Dorinne, Pont-de-Bonne, Royseux). Where the formation is thicker, the crinoidal packstone MF3 dominates in the upper part.
The bioclastic wackestone and mudstone are only observed in the basal part of the Martinrive Fm.

In the Soignies Mbr, MF1-2 alternate with MF3 in the lower two thirds of the section but MF3-4 tend to be more common in the upper third, witnessing a probable decrease of hydrodynamic conditions and deepening (Hibo, 1994), perhaps in link with a higher subsidence rate known in the HAS (Poty et al., 2001). 

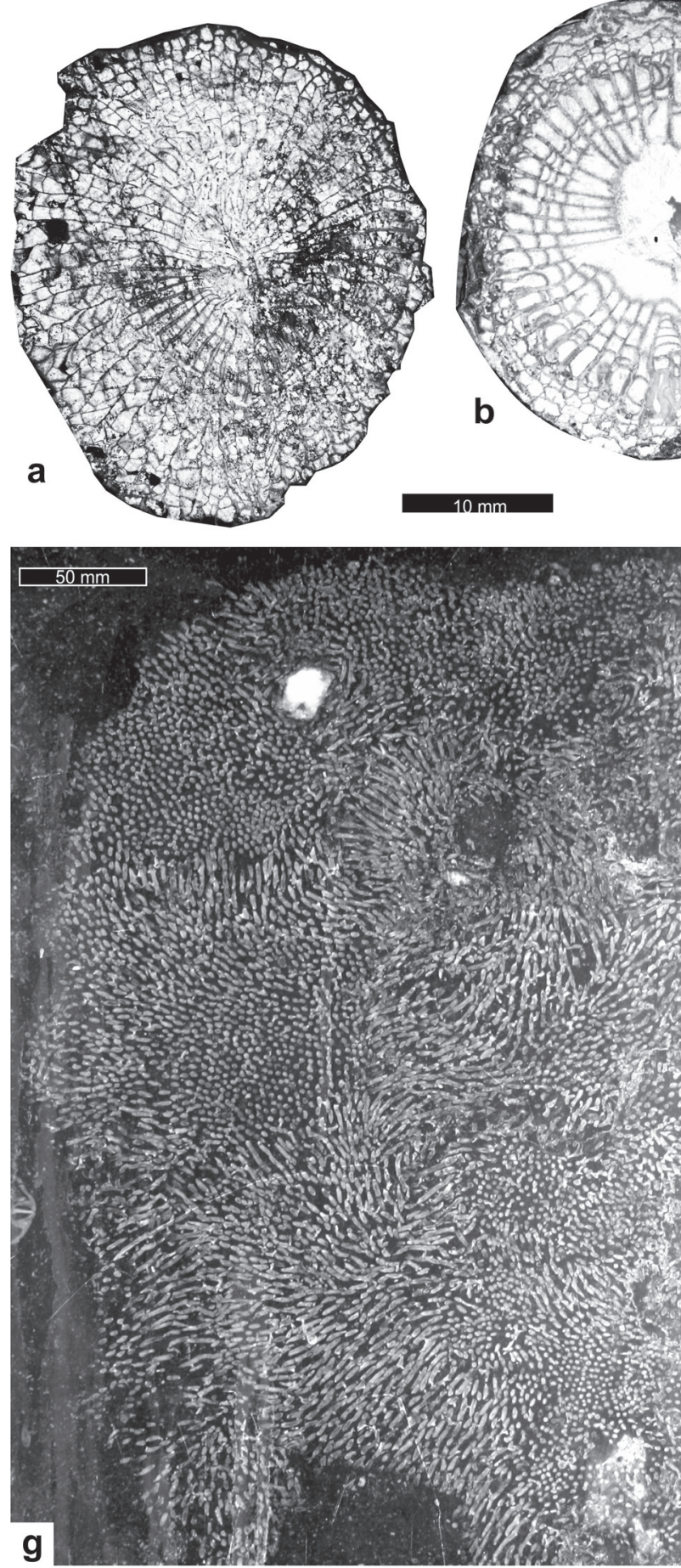
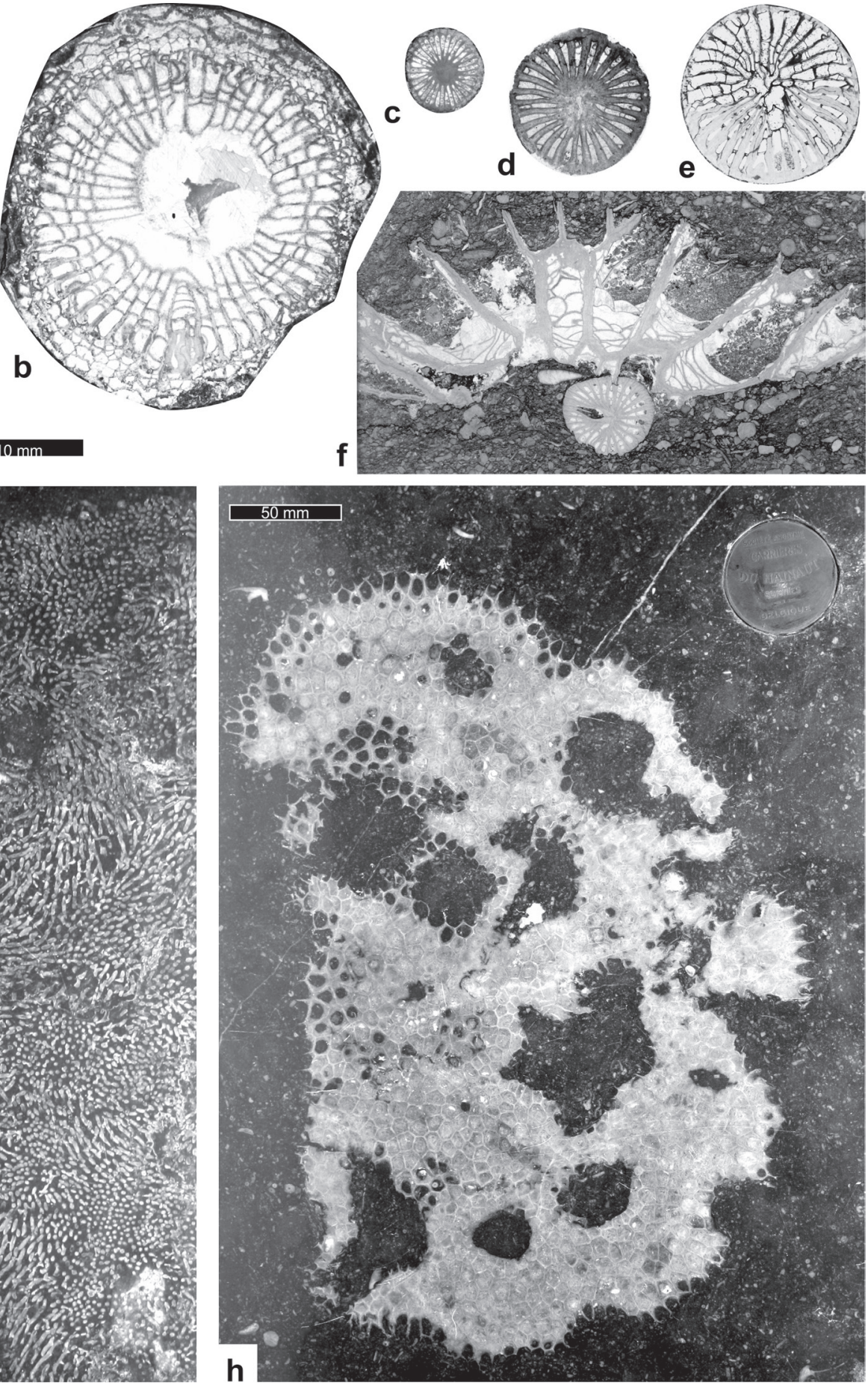

Figure 9. Corals from the Belgian Tournaisian encrinites: a: Caninophyllum patulum, in transverse section (TS), La Préalle quarry, Chanxhe (PAULgPré1994/20); b: Siphonophyllia cylindrica, TS, Pont-de-Bonne quarry, (PAULg-PdB2013/29c); c: Cyathaxonia cornu, TS, Gauthier-Wincqz quarry, Soignies (PAULg-GW/9IIa); d: Sychnoelasma konincki, TS, Gauthier-Wincqz quarry, Soignies (PAULg-GW2017-11c); e: Caninia cornucopiae, transverse section, Soignies quarry (PAULg-SGN1986/24a); f: "Michelinia megastoma" in longitudinal section, growing on a Zaphrentites cf. crassus, TS, La Préalle quarry, Chanxhe (PAULg-PRE/24); g: polished slab of "Petit Granit de Soignies" with a large colony of Syringopora sp., Soignies quarry (PAULg-20180111/1); h: polished slab of "Petit Granit de Soignies" with a large colony of "Michelinia megastoma" in TS, note the holes, probably left after the decay of a soft-bodied symbiont, Soignies quarry (PAULg-20180111/2).

The grain-supported microfacies MF1-3 all display features that point to a tempestite origin: a random orientation of the grains, the poor sorting, lack of grading and dark colour. The disarticulation of the skeletal elements and the erosion of the crinoid columnals (cf. CEI) also support a multiple reworking by successive hydrodynamic events, though it can be explained by other taphonomic processes. Sedimentary structures such as hummocky cross-stratifications on top of beds and the concentration of bioturbations in some horizons also indicate that the sediment accumulated as amalgamated tempestites. The amalgamation is suggested by the absence of the grading usually observed in individual tempestites and by the homogeneity of microfacies throughout the deposits (Seilacher \& Aigner, 1991; Puga-Bernabéu \& Aguirre, 2017). Consequently, it is considered that the entire "Petit Granit" facies was deposited under the fairweather wave base and within the storm wave zone.

The relatively high erosion (cf. CEI 2-3) of the columnals would suggest a transportation, but predation and bioerosion cannot be excluded, though rarely observed in thin section. At the opposite, the lack of sorting pleads for a limited transportation and is better explained by short-living high-energy conditions which are however compatible with the action of storms. With such limited transportation, the crinoid elements acted as (para-) autochtonous sedimentary particles produced and accumulated 


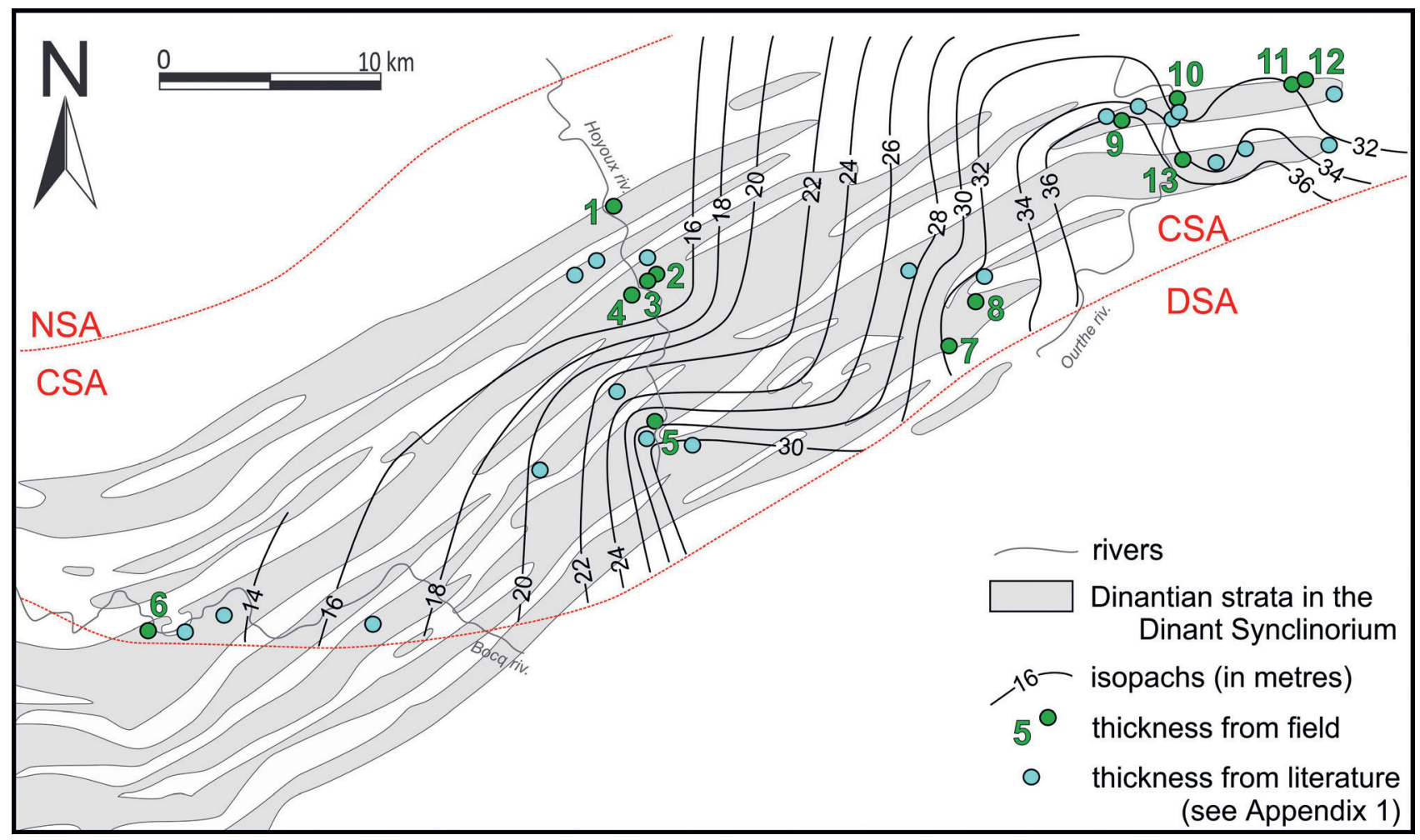

Figure 10. Isopach map showing the thickness variation of the Ourthe Fm throughout the Condroz sedimentation area (see Appendix 1 for the origin of data). Note that the Dinantian strata are only drawn for the CSA.

in the crinoidal meadow (Meyer \& Meyer, 1986; Llewellyn \& Messing, 1991). The disarticulation of the crinoid skeleton being mostly due to the decay of connecting tissues, the preservation of complete individual would require a rapid burial with no subsequent reworking. This constant reworking thus explains the total absence of complete specimen in the Ourthe Fm and the poor preservation of rare articulate crinoids in the Soignies Mbr (see examples in Donovan, 1991).

These massive encrinites made of disarticulated crinoids are similar to other region-covering crinoidal limestones such as the Burlington Limestone (lowermost Viséan of Missouri and Iowa) or the Sadler Ranch Fm (Lower to Middle Devonian of Nevada). As they share similar depositional and taphonomic characters, they are all referred to Burlington-type encrinites (Ausich et al., 1999b) or regional encrinites (Ausich, 1997).

\subsection{Thickness and carbonated production}

In order to interpret the lateral variations in thickness of the Ourthe Fm, punctual thicknesses were compiled from the literature (Libert, 1911; Groessens, 1978), from a regional study (ISSeP, 1994) and measurements in the field (see Appendix 1). The thickness, measured in metres, is considered as an elevation with the base of the Ourthe Fm corresponding to the level $0 \mathrm{~m}$. The Inverse Density Weighting (IDW) function from ArcGISC was used for interpolation, and the resulting thickness is displayed on an isopach map (Fig. 10).

As presented on Figure 10, the thickness of the Ourthe Fm increases eastwards with a maximal value in the Ourthe valley (eastern CSA) and a minimum value situated in the Bocq valley (SW CSA). The thickness decreases northwards where the equivalent of the Ourthe Fm in the Namur Dolostone Group is $11 \mathrm{~m}$-thick in the Marche-les-Dames quarry (Poty, 2016). This reduction is probably related to the more proximal position on the platform and the gradual passage to the oolithic Hastenrath Mbr that deposited in more dynamic conditions above the fair-weather wave base. In the SE region, the isolines are stopped because the Ourthe Fm passes gradually to the Leffe Fm and to the Waulsortian facies in the transitional area between the CSA and the DSA The lack of data between the Hoyoux and Bocq valleys in the CSA is explained by a lack of outcrops in this region where the "Petit Granit" was very scarcely quarried (Libert, 1911). The shape of the isopach map is therefore more speculative in this zone.
If the top of the formation is taken as a reference, it would indicate a gentle slope of the ramp c. $4^{\circ}$ eastwards. In the central CSA (Les Avins), the slope is more abrupt with a local increase to $20^{\circ}$. It suggests the local development of a shoal in this area. Note that the two preferential directions in the isolines are $\mathrm{N} 10^{\circ} \mathrm{E}$ and $\mathrm{N} 100^{\circ} \mathrm{E}$. These directions are parallel to the boundaries of faulted blocks defined during the Famennian by Thorez \& Dreesen (1986) and identified in the Carboniferous by Poty (1997) and Poty \& Delculée (2011). The E-W thickness gradient is thought to be linked to a different subsidence and accommodation of the eastern CSA compared to the central CSA. However, it cannot be excluded that differences in thickness resulted from local differences in carbonate production. The carbonate production of the crinoidal meadows is here provided by two distinct approaches.

The first approach is based on geological settings. The extension of the CSA covered by the Ourthe Fm estimated by the geological map (de Béthune, 1954) is c. $600 \mathrm{~km}^{2}$. Hence an area of $1200 \mathrm{~km}^{2}$ if a reduction of $50 \%$ after folding-thrusting is taken into account (Hance et al., 1999). The thickness map gives a variation of the thickness between 15 to 45 metres i.e. a constant average slope for the ramp of $4^{\circ}$. A total volume of sediment of $540 \mathrm{~km}^{3}$ is estimated for the Ourthe Fm in the CSA. The duration of deposition of the Ourthe Fm is unknown but can be approached by comparison with the Landelies Fm, a lower Tournaisian crinoidal limestone deposited in similar settings (Poty 2016) and also interpreted as a highstand system track (HST). It is thus considered that the duration of the deposit is similar and is approximately equal to $560 \mathrm{kyr}$ ( 28 cycles of 20,000 years; Poty, 2016). It results an average carbonated production rate of $1580 \mathrm{~cm}^{3} / \mathrm{m}^{2}$.y. Moreover, taking into account the dominance of grainstone facies where the crinoid elements represent $75 \%$ of the whole rock, the estimated crinoidal production is $1200 \mathrm{~cm}^{3}$ $\mathrm{m}^{2}$.y. This rate may seem very high compared to those calculated for the Mesozoic crinoidal limestones (c. $360 \mathrm{~cm}^{3} / \mathrm{m}^{2}$.y; David \& Leroux, 2000) or those measured in recent crinoid communities (c. $20 \mathrm{~cm}^{3} / \mathrm{m}^{2}$.y; Messing et al., 2007). Crinoidal meadows were presumably denser during the Tournaisian due to a higher diversity of the crinoids and more partitioned ecosystem at this time (Simms, 1999; Kammer \& Ausich, 2006).

The second approach is based on an ecological hypothesis: despite the lack of data regarding the carbonated production of 
crinoids during the Tournaisian, it is possible to extrapolate a columnal production rate $\left(\mathrm{cm}^{3} / \mathrm{y}\right)$ only related to the columnal diameter. Published data on Mesozoic crinoids (David \& Leroux, 2000) and Recent crinoids (Messing et al., 2007) show that columnal diameter plotted against production rate can be expressed by an exponential function (Appendix 2). If this equation is applied to each diameter proportion measured for each quarry, an average columnal production rate of $90 \mathrm{~cm}^{3} / y$ in the Ourthe Fm and $105 \mathrm{~cm}^{3} / \mathrm{y}$ in the Soignies Mbr is obtained.

Moreover, the crinoid density in the meadow was less than 20 individuals per square metre after Baumiller \& Rome (1998) and David \& Leroux (2000). At the opposite, a population density should have been higher than $10 \mathrm{ind} . / \mathrm{m}^{2}$ to produce the observed volume of columnals (David \& Leroux, 2000). Thus an average density of individuals of $15 \mathrm{ind} . / \mathrm{m}^{2}$ is assessed as an intermediate value compared to the few data available in the literature. Hence this value multiplied by the columnal production rate calculated above, a carbonated production rate of $1350 \mathrm{~cm}_{\text {columnal }}^{3} / \mathrm{m}^{2} . y$ is obtained. The rate is relatively similar to the one computed from geological hypothesis. Both approached based on completely independent hypothesis yield similar conclusions.

\subsection{Parataxonomy}

Only two species (Poteriocrinites crassus and Platycrinites laevis) were cited by de Koninck \& Le Hon (1854) from the Belgian Upper Tournaisian encrinites. Specific identification is not possible as the taxonomy of Crinoidea is based on the characters of the calyx. Though, the calyxes are extremely rare in the Ourthe Fm and Soignies Mbr due to complete disarticulation in this highly hydrodynamic environment, as often the case (Brett $\&$ Seilacher, 1991, Ausich \& Sevastopoulo, 1994). The diversity can nevertheless be estimated from disarticulated elements as demonstrated by Thuy et al. (2014) for ophiurids, Thompson \& Denayer (2017) for palaechinids and by Donovan \& Sevastopulo (1985) for crinoids. Even in disarticulated state, the crinoids present some characters: size, lumen to columnal diameter ratio, lumen shape, morphology of the columnal and occurrence of cirri. To infer the taxonomic diversity of crinoids in the Belgian example, these characters are sufficient and the parataxonomy developed by Moore \& Jeffords (1968) on the columnals observed in thin sections was used. Measured columnal diameters display a polymodal distribution (Fig. 11) pointing to the biodiversity of the Tournaisian crinoidal meadows in Belgium.

It has to be noted that there is a poor correlation between the morphology of the columnals and the crown of crinoids with few exceptions such as Gilbertsocrinus, Camptocrinus and some Platicrinitidae (Ausich, written communication, April 2018). Moreover a single taxon produces more than one type of columnal (e.g. columns, cirri, rhizoids and arms) whereas several species not taxonomically related may produce similar columnals. Consequently the correlation attempted here is highly hypothetical and unresolved and only used as an approach of the fossil diversity.

The genera Elytroclon and Ilematerisma and representatives of the Flucticharacidae and Excesiodiscidae are all characterised by circular columnal with a small circular lumen (Fig. 12a). Elytroclon and Ilematerisma have a lumen larger than those observed here. In the present material, the columnals having a diameter between 0.3 and $1 \mathrm{~mm}$ possibly correspond to remains of Flucticharacidae, whereas columnals 1 to $2.5 \mathrm{~mm}$ in diameter possibly correspond to Excesiodiscidae.

The members of the Rhodocrinitidae and Excesiodiscidae families display circular columnals with a middle-sized circular lumen (Fig. 12b). The Rhodocrinitidae are easily identified by their small columnal diameter $(<1 \mathrm{~mm})$, whereas the Excesiodiscidae have a larger columnal diameter ( $>1 \mathrm{~mm}$, Fig. 11).

The genera Dierocalipter, Rhysocamax, Stiberostaurus and Graphosterigma, as well as members of the Cyclomischidae family have circular columnals with a large circular lumen (Fig. 12d). Dierocalipter and Rhysocamax have a smaller diameter than Stiberostaurus and Graphosterigma. The Cyclomischidae could present a broad range of columnal diameters.

Members of the Platycrinitidae family display elliptical columnals with a middle-sized circular lumen. The latter are rather abundant in the Soignies Mbr (Fig. 12e, g, h, j).

The genera Gilbertsocrinus and Floricyclus both display circular columnals with a pentalobate lumen (Fig. 12c, k) but Floricyclus is rejected because of its convex profile which has not been observed on the macroscopic samples collected in the field.

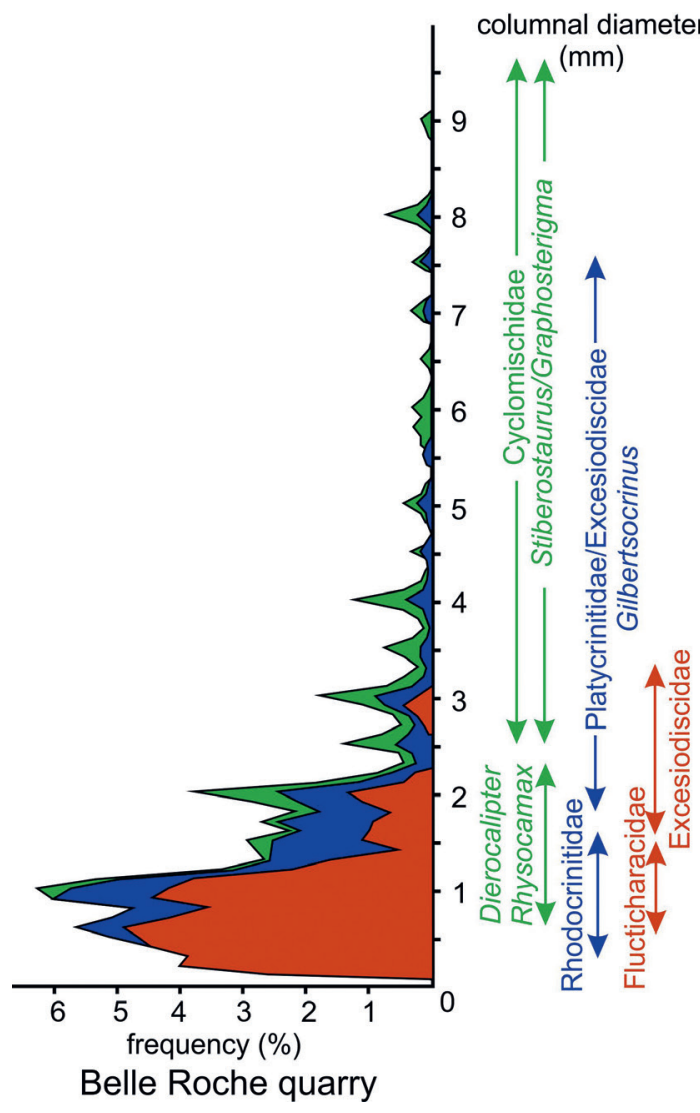

Belle Roche quarry
Columnal with

$\square$ - large lumen $(D>0.4)$

- middle-sized lumen $(D \sim 0.3)$

- small lumen $(D<0.15)$
Figure 11. Frequency histograms of the crinoid columnal diameter through the Ourthe Fm and Soignies Mbr exemplified by the Belle Roche and GauthierWincqz quarries. In addition are presented the potential taxa that yielded the columnal, sorted after their diameter. 

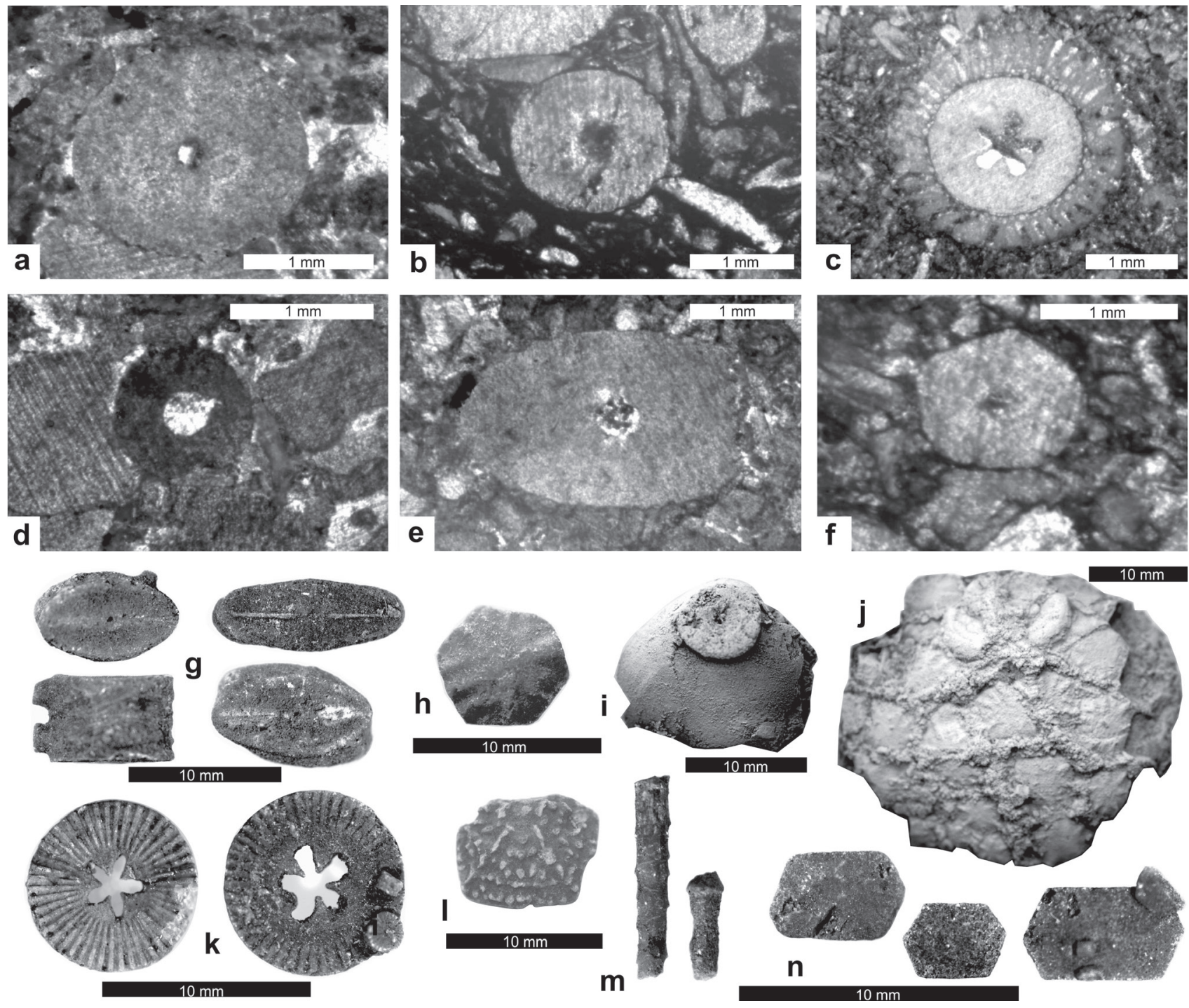

Figure 12. Echinoderm remains from the Belgian Tournaisian encrinite; a-f are in thin section. a: circular columnal with small lumen, possibly from a flucticharacid, Pont-de-Bonne quarry (PAULg-PdB-2/1); b: circular columnal with moderately large lumen, possibly from an excesiodiscid, Grispierre quarry, Ouffet (PAULg-GRI-19/1); c: circular columnal with pentalobate lumen, possibly from Gilbertocrinus sp., encrusted by a fistuliporid bryozoan, La Préalle quarry, Chanxhe (PAULg-PRE-9/1); d: circular columnal with large lumen, from an undetermined crinoid, Pont-de-Bonne quarry (PAULgPdB-2/2); e: elliptical columnal with a circular lumen, possibly from a platycrinitid, Grispierre quarry, Ouffet (PAULg-GRI-8/1); f: pentagonal columnal with a small circular lumen, possibly Fascicrinus sp., Grispierre quarry, Ouffet (PAULg-GRI-19/2); g: four elliptical columnal showing the typical twist of the platycrinitids, Gauthier-Wincqz quarry, Soignies (PAULg-GW>30/1 to 4); h: undetermined calicular plate of a platycrinitid, Gauthier-Wincqz quarry, Soignies (PAULg-GW-22-25/1), i: fragment of calyx, Gauthier-Wincqz quarry, Soignies (PAULg-GW/1); j: crushed calyx of a platycrinitid (Platycrinites laevis? cf. de Koninck \& Le Hon, 1854), Gauthier-Wincqz quarry, Soignies (PAULg-GW/2); k: two circular columnar with pentalobate lumen, possibly from Gilbertocrinus sp., Gauthier-Wincqz quarry, Soignies (PAULg-GW>10/1 to 2); 1: ornamented calicular plate from an undetermined crinoid, Gauthier-Wincqz quarry, Soignies (PAULg-GW/3); m: fragments of spines from an undetermined palaechinid, Gauthier-Wincqz quarry, Soignies (PAULg-GW-22-25/2); n: three ambulacral plates from an undetermined palaechinid, Gauthier-Wincqz quarry, Soignies (PAULg-GW-22-25/3).

Pentagonal columnals with a circular lumen (Fig. 12f) occur in thin sections but are usually badly preserved and their identification is uneasy. After Donovan (written communication, February 2017) this kind of columnal could possibly belong to Fascicrinus sp. However, the genus Fascicrinus is limited to the Late Ordovician (Webster, 2003).

Despite their abundance during the Mississippian of $\mathrm{N}$ America, blastoids seem to have been less common in Europe during the Tournaisian (Waters, 1990). Some occurrences are known in the late Tournaisian of Tournai (Marcuda, 1967), but none are known with certainty from the "Petit Granit". As stated before, crinoid calyxes are extremely rare in these facies, hence their diversity is only approached by the columnal-based parataxonomy. As there are no striking differences between dissociated blastoid, rhombiferan and crinoid columnals, the presence of the first two cannot be proven or rejected. Nevertheless, it would not be surprising to find groups of blastoid living amongst crinoids as described in N America (Waters \& Sevastopulo, 1984; Ausich, 1999a, b).

\subsection{Faunal assemblage}

Most of the crinoid species identified in the Ourthe Fm and Soignies Mbr (Fig. 12a-1) have already been identified in some others Tournaisian encrinites, notably in the NAmerica (i.e. Moore \& Jeffords, 1968; Ausich, 1999a, b), in the British Isles (Waters \& Sevastopulo, 1984; Lane et al., 2001) and in China (Lane et al., 1997; Webster et al., 2009). This widespread distribution reflects the fact that crinoids were generalists and took advantage of the appropriate living conditions of the environment during the Tournaisian. Some other suspension-feeder organisms have been closely associated to crinoids since the Lower Paleozoic (Ausich \& Bottjer, 2007): sponges, corals, bryozoans, brachiopods and other echinoderms frequently occupied the lower tier of the environment. Following the observations in the field and in thin sections, here is proposed a distribution of these organisms.

The tier $1(0 \rightarrow+5 \mathrm{~cm})$ : palaechinids, straparollid gastropods (Fig. 13g), trilobites (Phillipsia sp., Fig. 13k) (Hahn \& Hahn, 1988) and holothurids comprised the vagile part. Palaechinids (Fig. 12m, 

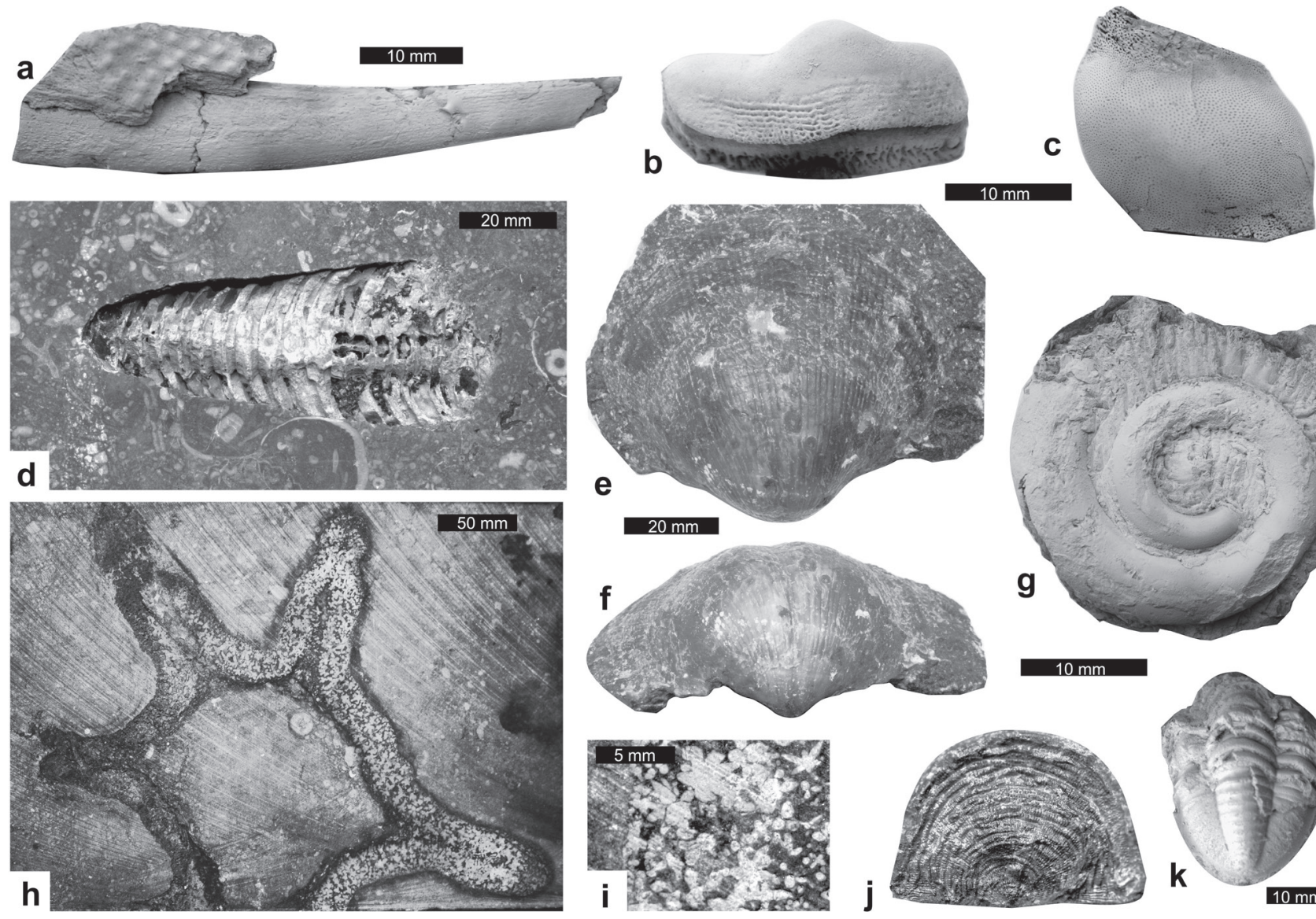

Figure 13. Macrofauna remains from the Belgian Tournaisian encrinite; a: undetermined dorsal spine of undetermined hybodontoid chondrychthian, GauthierWincqz quarry, Soignies (PAULg-GW/4); b: isolated tooth of the holocephalan condrychthian Helodus sp., Sprimont quarry (PAULg-SPR-1/5057); c: isolated tooth of Deltodus sublaevis, Soignies quarry (PAULg-SGN-5/6036); d: undetermined actinoceratoid cephalopod (Rayonnoceras?), undetermined quarry in the Ourthe valley (historical collection PAULg-20171212/1); e-f: Spirifer (Mesochorispira) konincki, undetermined quarry in the Ourthe valley (historical collection PAULg-20171212/2); g: undetermined straparollid gastropod, Sprimont quarry (historical collection PAULg-20171212/7); h-i: Asteractinella expansa sponge in transverse section (i is a close-up view of the spicules), Gauthier-Wincqz quarry, Soignies, "Pas de Loup" bed (historical collection PAULg-20180130/01); j: Leptagonia sp., Gauthier-Wincqz quarry, Soignies (PAULg-GW>30/5); k: phillipsid trilobite, Soignies quarry (PAULg-Soi-20171212/6).

n) are well-represented in the Ourthe Fm and could be one of the principal predators of crinoids as they are presently (Baumiller et al., 2008). The sessile guild comprised brachiopods (Leptagonia sp. (Fig. 13j), productids s.l., spiriferids s.l., Undispirifer, Mesochorispira konincki (Fig. 13e-f)), rugose corals (Cyathaxonia cornu (Fig. 9c), Caninia cornucopiae (Fig. 9e), Caninophyllum patulum (Fig. 9a), Siphonophyllia cylindrica (Fig. 9b), Zaphrentites cf. crassus (Fig. 9f), Sychnoelasma konincki (Fig. 9d)), tabulate corals (micheliniids, syringoporids (Fig. 9g-h)), bryozoans (Fig. 12c) and sponges (Asteractinella expansa (Fig. 13h-i)).

Based on the proportions of columnals of each morphology described above and with the hypothetic assumption that they are associated to the different taxa as suggested by parataxonomy (see 5.3.), a tiering model can be proposed for the Belgian Tournaisian encrinites (Fig. 14). In comparison with the tiering model proposed by Ausich \& Bottjer (1982, 2007), the Flucticharacidae, the Rhodocrinitidae, Dierocalipter and Rhysocamax lived in the tier $2(+5 \rightarrow+20 \mathrm{~cm})$, the Excesiodiscidae and the Platycrinitidae probably occupied the tier $3(+20 \rightarrow+50 \mathrm{~cm})$. Then the tier $4(+50$ $\rightarrow+100 \mathrm{~cm}$ ) was probably occupied by long-stemmed crinoids, such as Stiberostaurus, Graphosterigma and the Cyclomischidae. As suggested by the proportion of measured diameter of columnals, the proportions of individuals is approximately constant from one quarry to the other: $55-65 \%$ of the crinoid community occupied the tier 2, 20-30\% occupied the tier 3 and finally $10-15 \%$ of the crinoids occupied the tier 4 .

The nekton was mainly comprised of holocephalan and hybodontid chondrychthians whose teeth are common in the Tournaisian encrinites (Fig. 13a-c). Actinoceratoid cephalopods (Rayonnoceras?, Fig. 13d) were occasional dwellers of the crinoid meadow. A great amount of bioturbation is present throughout the
Soignies Mbr and the Ourthe Fm, but these endobenthic traces have not been identified and studied.

The environment was clearly dominated by the suspension feeders but the occurrence of nektonic and benthic macrophages witnesses the complexity of the ecosystem of the crinoidal meadows despite the crinoid dominance.

\section{Discussions}

Judging from the columnal morphologies, all the species and genera of crinoids that comprised the crinoidal meadow in the Ourthe Fm were already present at the top of the Yvoir Fm, generally characterised by a peloidal and crinoidal grainstone (MF2). The great amount of peloids at the top of the Yvoir Fm could be attributed to a relative abundance of macrophages in the crinoidal meadow, preventing or diluting the accumulation of columnals. At the transition between the Yvoir and the Ourthe formations the rate of columnal production increased exponentially, enabling the deposit of a truly massive crinoidal limestone. The passage from the Yvoir Fm (TST) to the Ourthe Fm (HST) also recorded an increase in hydrodynamic settings that also explain the drastic decrease of peloidal content.

Peaks in the curve of maximum columnal diameter are correlated throughout the CSA(Figs 5, 7, 8), in the "Bancs minces", top of "Gris Banc" and in the "Bancs noirs". Those maxima can be explained by hydrodynamic effects but it has to be noted there is no correlation with the columnal erosion index (CEI).

During the Tournaisian, S Belgium is located at a latitude of $15^{\circ} \mathrm{S}$ (Golonka, 2007) within the hurricane area (Yao et al., 2016). The crinoidal meadows were regularly swept by tropical storms and cyclically by hurricanes of higher intensity. Indeed high fragmentation of skeletons, rounded fragments of shells and hummocky cross- 


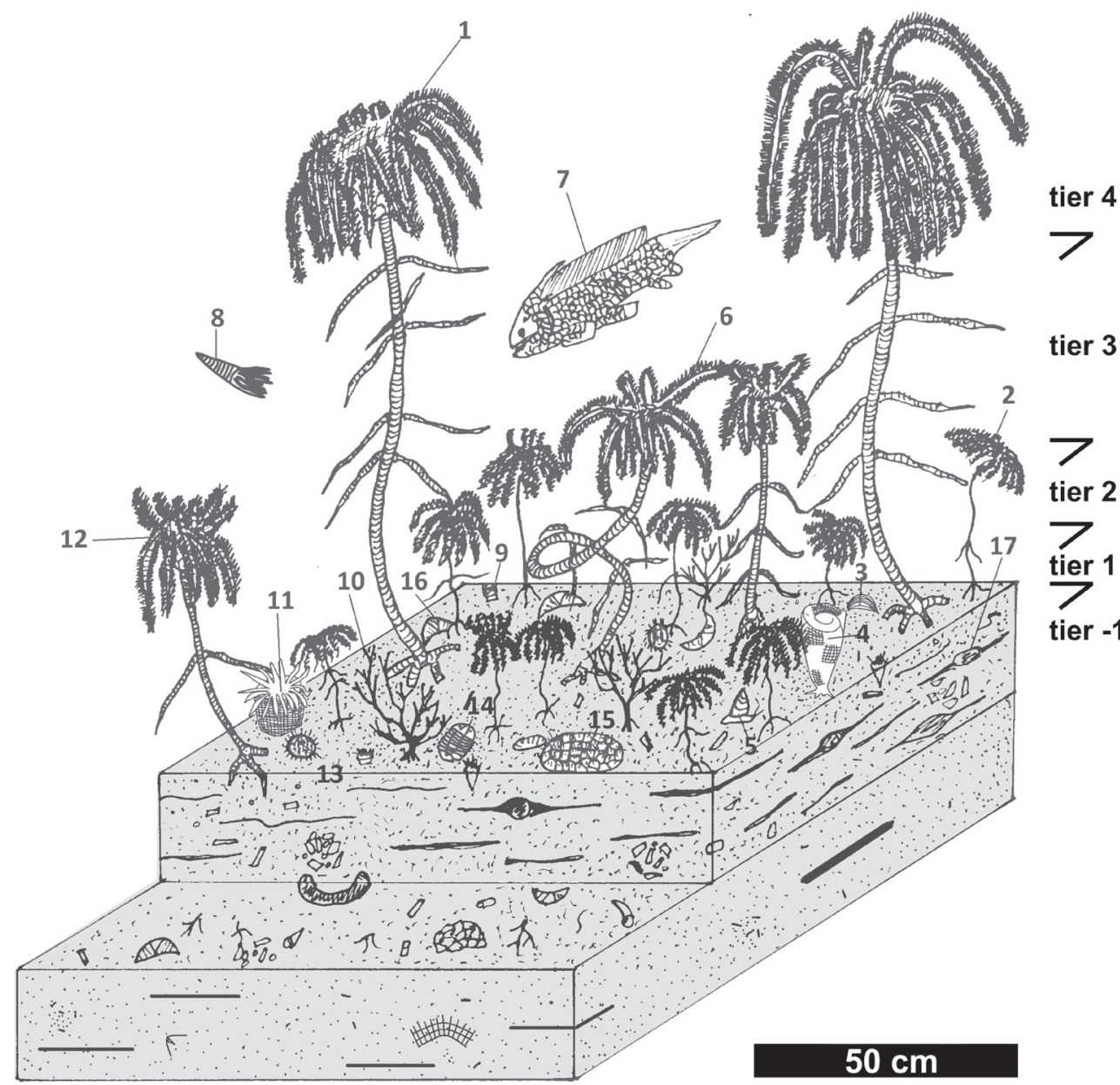

Figure 14. Reconstruction of the "Petit Granit" community based on estimated density and tiering of crinoids and other fauna in the Ourthe Fm. Legend: 1: longstemmed crinoids (possibly Stiberostaurus, Graphosterigma or Cyclomischidae); 2 : short-stemmed crinoid (possibly Flucticharacidae, Rhodocrinitidae, Dierocalipter or Rhysocamax); 3: productid brachiopod; 4: reticulate bryozoan (Fenestella); 5: straparollid gastropod; 6: coiled crinoid (Platycrinitidae); 7: holocephalan chondrychthian; 8: orthoconic actinoceratoid (Rayonnoceras ?); 9 : small solitary rugose coral (Cyathaxonia cornu); 10: ramose bryozoan (rhomboporid); 11: large solitary rugose coral (Caninophyllum patulum); 12: intermediate-size crinoid (possibly Excesiodiscidae or Gilbertsocrinus); 13: palaechinid; 14: phillipsid trilobite; 15: massive tabulate coral (micheliniid); 16: spiriferid brachiopod; 17: burrow.

stratification in the Ourthe Fm indicate the deposition during storm events, as explained above. Except these periods of intense agitation, the environment was a weakly-agitated system with a seafloor relatively loose as suggested by brachiopods with a large lifting surface (Spiriferides, Leptagonia) enabling them to float on the sediment surface, branched bryozoans (Hyphasmoporidae) and rootshaped holdfasts of crinoids. Contrary to Hardy (1973) who placed the Tournaisian crinoidal meadow beneath storm wave base, the deposition of the Ourthe Fm is thought to have taken place between the fair-weather wave base and the storm wave base. Similar interpretations were provided for other Burlington-type crinoidal deposits in NW Europe (Waters \& Sevastopulo, 1984; Webster et al., 2003) and N America (Ausich, 1999b).

Slight microfacies variations are explained by hydrodynamic changes on the deposition area due to cyclic rise and fall of sea level (possibly $4^{\text {th }}$ order, Poty, 2016). A slight decrease of sea level would have indeed increased the hydrodynamics and washed out peloids, leaving a greater concentration of columnals.

As often observed in encrinites (e.g. David \& Leroux, 2000 and references within), the deposition area were covered with megadunes larger than high and moving during hydrodynamic events. As small particles accumulated in the depressions, the vertical succession of crinoidal grainstone and packstone observed in the sections could be interpreted as the vertical succession of dunes and interdunes deposits. Nevertheless the regularity of beds in the CSA and their lateral continuity along several kilometres do not confirm this interpretation.

At the top of the Ourthe Fm, a major fall of the sea level in the CSA induced a change of the microfacies to a crinoidal packstone. The boundary between the Ourthe and Martinrive formations is sharp with a switch to finer-grained facies where suspension feeder organisms disappeared and are replaced by thin-shelled gastropods, Kameana and plurilocular foraminifers. The large crinoids disappeared in the basal part of the Martinrive Fm in response to the development of unfavourable, more restricted facies.

\section{Conclusions}

Despite the monotonous appearance, the Tournaisian crinoidal meadows of $\mathrm{S}$ Belgium were not a poor and monotonous environment but a complex and well-organized community of organisms. The dominant suspension feeder organisms were divided into vertical tiers, and the presence of non-suspension feeder organisms, above and under the crinoidal meadow, is documented. The crinoids and associated suspension feeders formed an assemblage similar to those described from other encrinites, notably in the N America, in the British Isles and in China (e.g. Ausich, 1999a; Waters \& Sevastopulo, 1984; Webster et al., 2009) in similar settings of the Burlington-type regioncovering crinoidal deposits (Ausich et al., 1999b). The recurrent storm and hurricane events regularly annihilated the crinoid meadows and produced vast crinoidal gravel and sands deposited as amalgamated tempestites. The meadows finally disappeared from the Condroz and Hainaut sedimentation areas as the result of a change in the sedimentation following the emersion at the sequence boundary. Moreover, the detailed analysis of this falsely simple succession demonstrates the recovery of the marine environment after the collapse of the reefal ecosystem at the end of the Devonian (Ausich \& Kammer, 2013; Sallan et al., 2011).

\section{Acknowledgements}

The authors thank V. Fischer, E. Poty and A. Anceau for their patient guidance and their numerous advices and corrections, and Joël Laval for his technical support. We are particularly grateful for the assistance provided by W.I. Ausich, S.K. Donovan and T.K. Baumiller regarding crinoid ecology and identification. We thank the following companies for their assistance with the collection of present data in their quarries: SPRL Gripierres, Bram Moris, SprimontBlue ${ }^{\circledR}$ carrières de Sprimont, Renier Natuursteen, Mercier SPRL, Carrières du Bocq, Groupe Van Reeth-Hoefkens, and Les carrières de la pierre bleue belge. Finally, we thank the reviewers William Ausich (Columbus State University, Ohio) and Elise Nardin (Univsersité de Toulouse, France) for their constructive reviews. 


\section{References}

Amler, M.R.W \& Herbig, H.-G., 2006. Ostrand der Kohlenkalk-Plattform und Übergang in das Kulm-Becken im westlichsten Deutschland zwischen Aachen und Wuppertal. In Deutsche Stratigraphische Kommission (ed.), Stratigraphie von Deutschland VI - Unterkarbon (Mississippium). Schriftenreihe der Deutschen Gesellschaft für Geowissenschaften, 41, 441-477.

Anceau, A., 1993. Caractérisation des minéraux argileux des bentonites potassiques du Carbonifère inférieur de la Belgique et des régions limitrophes. Unpublished $\mathrm{PhD}$ thesis. Université de Liège, Belgium, $165 \mathrm{p}$.

Ausich, W.I. 1997. Regional encrinites: A vanished lithofacies. In Brett, C.E. \& Baird,G.C. (eds), Paleontological Events: Stratigraphic, Ecologic and Evolutionary Implications. Columbia University Press, New York, 509-519.

Ausich, W.I., 1999a. Lower Mississippian Hampton Formation at LeGrand, Iowa, USA. In Ausich, W.I., Brett, C.E., Hess, H. \& Simms, M.J. (eds), Fossil Crinoids. Cambridge University Press, Cambridge, 135-138.

Ausich, W.I., 1999b. Lower Mississippian Burlington Limestone along the Mississippi River Valley in Iowa, Illinois, and Missouri, USA. In Ausich, W.I., Brett, C.E., Hess, H. \& Simms, M.J. (eds), Fossil Crinoids. Cambridge University Press, Cambridge, 139-144.

Ausich, W.I. \& Bottjer, D.J., 1982. Tiering in suspension-feeding communities on soft substrata throughout the Phanerozoic. Sciences, 216, 173-174.

Ausich, W.I. \& Bottjer, D.J., 2007. Sessile invertebrates. In Briggs, D.E.G. \& Crowther, P.R. (eds), Palaeobiology II. Blackwell Publishing Ltd, Oxford, 384-386.

Ausich, W.I. \& Kammer, T.W., 2013. Mississippian crinoid biodiversity, biogeography, and macroevolution. Palaeontology, 56, 727-740. https://doi.org/10.1111/pala.12011

Ausich, W.I. \& Sevastopoulo, G.D., 1994. Taphonomy of Lower Carboniferous crinoids from the Hook Head Formation, Ireland. Lethaia, 27, 245-256. https://doi.org/10.1111/j.1502-3931.1994. tb01418.x

Ausich, W.I. \& Simms, M.J., 1999. Ecology and ecological interactions. In Hess, H., Ausich, W.I., Brett, C.E. \& Simms, M.J. (eds), Fossil Crinoids. Cambridge University Press, Cambridge, 55-59.

Ausich, W.I., Brett, C.E., Hess, H. \& Simms, M.J., 1999a. Crinoid form and function. In Ausich, W.I., Brett, C.E., Hess, H. \& Simms, M.J. (eds), Fossil Crinoids. Cambridge University Press, Cambridge, 3-30.

Ausich, W.I., Brett, C.E. \& Hess, H., 1999b. Taphonomy. In Ausich, W.I., Brett, C.E., Hess, H. \& Simms, M.J. (eds), Fossil Crinoids. Cambridge University Press, Cambridge, 50-54

Baumiller, T.K. \& Rome, E.F., 1998. The interference avoidance hypothesis and the spatial distribution of Endoxocrinus parrae (Crinoidea, Echinodermata). In Mooi, R. \& Telford, M. (eds), Echinoderms, Proceedings of the $9^{\text {th }}$ International Echinoderm Conference, 5-9 August, 1996. San Francisco, California, USA, $133-137$.

Baumiller, T.K., Mooi, R. \& Messing, C.G., 2008. Urchins in the meadow: paleobiological and evolutionary implications of cidaroid predation on crinoids. Paleobiology, 34/1, 22-34. https://doi. org/10.1666/07031.1

Brett, C.E \& Seilacher, A., 1991. Fossil Lagerstätten: a taphonomic consequence of event sedimentation. In Einsele, G., Ricken, W. \& Seilacher, A. (eds), Cycles and Events in Stratigraphy. SpringerVerlag, New-York, 283-297.

Chen, Z.-T. \& Yao, J.-H., 1993. Paleozoic Echinoderm Fossils of Western Yunnan. China. Geological Publishing house, Beijing, 102 p.

Conil, R., 1973. Les foraminifères du Tournaisien supérieur. Service géologique de Belgique, Professional papers, 5, 12-17.

Conil, R. \& Lys, M., 1977. Les transgressions dinantiennes et leur influence sur la dispersion et l'évolution des foraminifères. Mémoire de l'Institut géologique de l'Université de Louvain, 29, 9-55.

Conil, R., Groessens, E., Laloux, M., Poty, E. \& Tourneur, F., 1991. Carboniferous guide foraminifera, corals and conodonts in the Franco-Belgian and Campine Basins: their potential for widespread correlation. Courier Forschungsinstitut Senckenberg, 130, 15-30.

De Bethune, P., 1954. Carte géologique de la Belgique au 1/500 000. Atlas de Belgique, planche 8 . Académie royale de Belgique, Bruxelles.

David, J. \& Leroux, M., 2000. Modèle actuel de production bioclastique par les crinoïdes pédonculés. Application au calcaire à entroques d'Euville (Oxfordien de la Meuse). Comptes rendus de l'Académie des Sciences, IIA, Earth and Planetary Sciences, 330, 111-116. https://doi.org/10.1016/S1251-8050(00)00107-5

De Koninck, L.-G., 1887. Faune du Calcaire carbonifère de la Belgique. Sixième partie : les brachiopodes. Hayez, Bruxelles, 154 p.

De Koninck, L.-G. \& Le Hon, H.-S., 1854. Recherches sur les crinoïdes du terrain carbonifère de la Belgique. Hayez, Bruxelles, 205 p.
Demanet, F., 1934. Les brachiopodes du Dinantien de la Belgique Mémoires du Musée royal d'Histoire naturelle de Belgique, 61, 116 p.

Denayer, J., Poty, E. \& Aretz, M., 2011. Uppermost Devonian and Dinantian rugose corals from Southern Belgium and surrounding areas. Kölner Forum für Geologie und Paläontologie, 20, 151-201.

Donovan, S.K., 1991. The taphonomy of echinoderms: Calcareous multielement skeletons in the marine environment. In Donovan, S.K (ed.). The Processes of Fossilization. Columbia University Press, New York, 241-269.

Donovan, S.K. \& Sevastopulo, G., 1985. Crinoid arms from Salthill Quarry, Clitheroe, Lancashire. Proceedings of the Yorkshire Geological Society, 45, 179-182.

Doremus, E. \& Hennebert, M., 1995. Carte géologique de Wallonie: Lens - Soignies 38/7-8. 1/25 000. Namur, Ministère de la Région wallonne, Direction générale des ressources naturelles et de l'environnement, avec une notice explicative de $54 \mathrm{p}$.

Głuchowski, E., 2002. Crinoids from the Famennian of the Holy Cross Mountains, Poland. Acta Palaeontologica Polonica, 47, 319-328.

Golonka, J., 2007. Phanerozoic paleoenvironment and paleolithofacies maps: Late Paleozoic. Geologia, 33/2, 145-209.

Gorzelak, P., Blazejowski, B., Uchman, A. \& Hanken, N-M., 2013. First record of catacrinid crinoid from the Lower Permian of Spitsbergen. Polish Polar research, 34/2, 134-150. https://doi.org/10.2478/ popore-2013-0010

Groessens, E., 1971. Les conodontes du Tournaisien supérieur de la Belgique, note préliminaire. Service géologique de Belgique, Professional papers, 4, 1-29.

Groessens, E., 1973. La Formation du Bocq à Yvoir. Service géologique de Belgique, Professional papers, 5, 1-11.

Groessens, E., 1975. Distribution des conodontes dans le Dinantien de la Belgique. International Symposium on Belgian micropaleontological limits from Emsian to Viséan, Namur 1974. Service géologique de Belgique, publication 17, 1-193.

Groessens, E., 1978. La série tournaisienne dans la région des Ecaussinnes (Bord Nord du Synclinorium de Namur). Bulletin de la Société belge de Géologie, 87, 67-72.

Groessens, E., 1981. L'industrie du marbre en Belgique. Mémoire de l'Institut géologique de 1'Université de Louvain, 31, 219-253.

Groessens, E., 1994. L'origine et l'évolution de l'expression "Petit Granit”. Bulletin de la Société belge de Géologie, 102, 271-276.

Hahn, G \& Hahn, R., 1988. The biostratigraphical distribution of Carboniferous limestone trilobites in Belgium and adjacent areas. Bulletin de la Société belge de Géologie, 97/1, 77-93.

Hance, L., Ghysel, P., Laloux, M., Dejonghe, L. \& Mansy, J.L., 1999. Influence of heterogeneous lithostructural layering on orogenic deformation in the Variscan Front Zone (eastern Belgium) Tectonophysics, 309, 161-177. https://doi.org/10.1016/S00401951(99)00137-7

Hance, L., Poty, E. \& Devuyst, F-X., 2001. Stratigraphie séquentielle du Dinantien type (Belgique) et corrélation avec le nord de la France (Boulonnais, Avesnois). Bulletin de la Société Géologique de France, 172/4, 411-426. https://doi.org/10.2113/172.4.411

Hance, L. Poty, E. \& Devuyst, F.X., 2006. Ivorian. In Dejonghe, L. (ed.), Current status of chronostratigraphic units named from Belgium and adjacent areas. Geologica Belgica, 9/1-2, 117-122.

Hardy, A-F., 1973. Etude lithologique et paléoécologique du "Petitgranit" de l'Ourthe. Unpublished master thesis, Université de Liège, Belgium, $60 \mathrm{p}$.

Hibo, D., 1994. Le petit-granit de la vallée de la Meuse et du bassin carrier de Soignies: approche du contexte sédimentologique et comparaison. Bulletin de la Société belge de Géologie, 102/3-4, 359-378.

ISSeP (Institut Scientifique de Service Public), 1994. Etude des réserves potentielles exploitables de Petit granit zone Est, 1990-1993, rapport final et annexes. Unpublished report, Liège, $115 \mathrm{p}$.

Kammer, T.W. \& Ausich, W.I., 2006. The "Age of Crinoids": A Mississippian biodiversity spike coincident with widespread carbonate ramps. Palaios, 21/3, 238-248. https://doi.org/10.2110/ palo.2004.p04-47

Kasig, W., 1980. Dinantian carbonates in the Aachen region. Mededelingen Rijks Geologische Dienst, 32/6, 44-52.

Lane, N.G., Waters, J.A. \& Maples, C.G., 1997. Echinoderm faunas of the Hongguleleng Formation, Late Devonian (Famennian), Xinjiang-Uygur Autonomous Region, People's Republic of China Paleontological Society Memoir, 47, 1-43. https://doi.org/10.1017/ S0022336000061485

Lane, N.G., Maples, C.G. \& Waters, J.A., 2001. Revision of Late Devonian (Famennian) and some Early Carboniferous (Tournaisian) crinoids and blastoids from the type Devonian area of North Devon. Palaeontology, 44, 1043-1080. https://doi.org/10.1111/14754983.00215 
Llewellyn, G. \& Messing, C.G., 1991. Local variations in modern crinoid rich carbonate bank-margin sediments. Geological Society of America Abstracts with Programs 23, 344.

Libert, J., 1911. Les carrières de petit-granit de la Province de Liège. Annales des Mines, 16, 803-930.

Marcuda, D.B., 1967. The Lower Carboniferous (Tournaisian) blastoids of Belgium. Journal of Paleontology, 41/2, 455-486.

McGhee, G.R.Jr., 1996. The Late Devonian Mass Extinction. Columbia University Press, New York, 303 p.

Messing, C.G., David, J., Roux, M., Améziane, N. \& Baumiller, T.K., 2007. In situ stalk growth rates in tropical western Atlantic sea lilies (Echinodermata: Crinoidea). Journal of Experimental Marine Biology and Ecology, 353, 211-220. https://doi.org/10.1016/j. jembe.2007.08.021

Meyer, D.L. \& Meyer, K.B., 1986. Biostratinomy of Recent crinoids (Echinodermata) at Lizard Island, Great Barrier Reef, Australia. Palaios, 1, 294-302. https://doi.org/10.2307/3514692

Moore, R.C. \& Jeffords, R.M., 1968. Classification and nomenclature of fossil crinoids based on studies of dissociated parts of their columns. University of Kansas, Paleontological Contributions, Echinodermata, 9, 1-86.

Poty, E., 1989. Distribution and palaeogeographic affinities of Belgian Tournaisian rugose corals. Memoirs of the Association of Australasian Palaeontologists, 8, 267-273.

Poty, E., 1997. Devonian and Tournaisian tectonics in the eastern and southeastern parts of the Brabant Massif (Belgium). In Camelbeeck, T., Sintubin, M. \& Vandycke, S. (eds), Belgian Symposium on structural Geology and Tectonics. Aardkundige Medelingen, 8, 143144.

Poty, E., 2016. The Dinantian (Mississippian) succession of southern Belgium and surrounding areas: stratigraphy improvement and inferred climate reconstruction. In Denayer, J. \& Aretz, M. (eds), Devonian and Carboniferous research: homage to Professor Edouard Poty. Geologica Belgica, 19/1-2, 177-200. http://dx.doi. org/10.20341/gb.2016.014

Poty, E. \& Chevalier, E., 2004. L'activité minière en Wallonie, situation actuelle et perspectives. Ministère de la Région wallonne, Jambes, $85 \mathrm{p}$.

Poty, E. \& Delculée, S., 2011. Interaction between eustacy and blockfaulting in the Carboniferous of the Visé - Maastricht area (Belgium, The Netherlands). Zeitschrift der Deutschen Gesellschaft für Geowissenschaften, 162/2, 117-126. https://doi.org/10.1127/18601804/2011/0162-0117

Poty, E., Hance, L., Lees, A. \& Hennebert, M., 2001. Dinantian lithostratigraphic units (Belgium). Geologica Belgica, 4/1-2, 69-93.

Poty, E., Devuyst, F-X. \& Hance, L., 2006. Upper Devonian and Mississippian foraminiferal and rugose coral zonations of Belgium and northern France: a tool for Eurasian correlations. Geological Magazine, 143, 829-857. https://doi.org/10.1017/ S0016756806002457

Puga-Bernabéu, A. \& Aguirre, J., 2017. Contrasting storm- versus tsunami - related shell beds in shallow-water ramps. Palaeogeography, Palaeoclimatology, Palaeoecology, 471, 1-14. https://doi. org/10.1016/j.palaeo.2017.01.033

Sallan, L.C., Kammer, T.W., Ausich, W.I. \& Cook, L.A., 2011. Persistent predator-prey dynamics revealed by mass extinction. Proceedings of the National Academy of Science, 108/20, 8335-8338. https://doi. org/10.1073/pnas.1100631108

Seilacher, A. \& Aigner, T., 1991. Storm deposition at the bed, facies and basin scale: the geologic perspective. In Einsele, G., Ricken, W. \& Seilacher, A. (eds), Cycles and Events in Stratigraphy. SpringerVerlag, New York, 249-267.

Simms, M.J., 1999. Systematics, phylogeny and evolutionary history. In Hess, H., Ausich, W.I., Brett, C.E. \& Simms, M.J. (eds). Fossil crinoids. Cambridge University Press, Cambridge, 31-40.

Thorez, J. \& Dreesen, R., 1986. A model of a regressive depositional system around the Old Red Continent as exemplified by fieldtrip in the upper Famennian "Psammites du Condroz" in Belgium. Annales de la Société géologique de Belgique, 109, 285-323.

Thompson, J. \& Denayer, J., 2017. Revision of echinoids from the Tournaisian (Mississippian) of Belgium and the importance of disarticulated material in assessing palaeodiversity. Geological Journal, 52/4, 529-538. https://doi.org/10.1002/gj.2783

Thuy, B., Gale, A.S., Stöhr, S. \& Wiese, F., 2014. Shallow-water brittle-star (Echinodermata: Ophiuroidea) assemblages from the Aptian (Early Cretaceous) of the North Atlantic: first insights into bathymetric distribution patterns. In Wiese, F., Reich, M. \& Arp, G. (eds), Spongy, slimy, cosy \& more: Commemorative Volume in Celebration of the $60^{\text {th }}$ Birthday of Joachim Reitner. Göttingen Contributions to Geosciences, 77, 163-182. https://doi.org/10.3249/ webdoc-3927
Tourneur, F., Conil, R. \& Poty, E., 1989. Données préliminaires sur les Tabulés et les Chaetetides du Dinantien de la Belgique. Bulletin de la Société belge de Géologie, 98/3-4, 401-442.

Waters, J.A., 1990. The palaeobiogeography of the Blastoidea (Echinodermata). In McKerrow, W.S. \& Scotese, C.R. (eds). Palaeozoic Palaeogeography and Biogeography. Geological Society, London, Memoirs, 12, 339-352. https://doi.org/10.1144/GSL. MEM.1990.012.01.33

Waters, J.A. \& Sevastopulo, G.D., 1984. The stratigraphical distribution and palaeoecology of Irish Lower Carboniferous blastoids. Irish Journal of Earth Sciences, 6, 137-154.

Webster, G.D., 2003. Bibliography and index of Paleozoic crinoids, coronates, and hemistreptocrinoids. Geological Society of America Special Paper, 363, 1758-1999.

Webster, G.D., Maples, C.G., Mawson, R. \& Dastanpour, M., 2003. A cladid-dominated early Mississippian crinoid and conodont fauna from Kerman province, Iran and revision of the glossocrinids and rhenocrinids. Journal of Paleontology, 77, 1-36. https://doi. org/10.1666/0022-3360

Webster, G.D., Waters, J.A. \& Chen, X., 2009. Revision of the Chen and Yao Devonian to Permian crinoids from western Yunnan. Palaeobiodiversity and Palaeoenvironment, 89, 169-160. https://doi. org/10.1007/s12549-009-0007-3

Yao, L., Aretz, M., Li, Y. \& Wang, X.-D., 2016. Gigantoproductid brachiopod storm shell beds in the Mississippian of South China: implications for their palaeoenvironmental and palaeogeographical significances. In Denayer, J. \& Aretz, M. (eds), Devonian and Carboniferous research: homage to Professor Edouard Poty. Geologica Belgica 19/1-2, 57-67. http://dx.doi.org/10.20341/ gb. 2015.021 
Appendix 1. Thickness of the Ourthe Fm (field measurement and published data) in each locality.

\begin{tabular}{|c|c|c|}
\hline & Location & $\begin{array}{l}\text { Thickness } \\
(\mathrm{m})\end{array}$ \\
\hline \multirow[t]{14}{*}{ Libert, 1911; Groessens, 1978} & & \\
\hline & Triffoy & 16.0 \\
\hline & Surroyseux & 21.9 \\
\hline & Vierset-Barse & 18.0 \\
\hline & Fond de Leval & 28.0 \\
\hline & Petit-Avin & 29.0 \\
\hline & Chanxhe-Poulseur & 28.5 \\
\hline & Chanxhe & 32.5 \\
\hline & Florzée & 33.0 \\
\hline & Lizen & 33.0 \\
\hline & Vien & 34.5 \\
\hline & Anthisnes & 34.0 \\
\hline & Ogné & 32.0 \\
\hline & Correux & 31.0 \\
\hline \multirow[t]{10}{*}{$\begin{array}{l}\text { ISSep, } 1994 \\
\text { (unpublished report) }\end{array}$} & & \\
\hline & Spontin & 13.3 \\
\hline & Seneffe & 26.3 \\
\hline & Porcheresse & 17.5 \\
\hline & Pailhe & 23.0 \\
\hline & Malihoux & 20.1 \\
\hline & Braibant & 17.0 \\
\hline & Anthisnes & 36.0 \\
\hline & Halleux & 35.0 \\
\hline & Rouvreux & 40.0 \\
\hline \multirow[t]{14}{*}{ Measured (this work) } & & \\
\hline & Dorinne & 15.0 \\
\hline & Vivaqua & 19.0 \\
\hline & Herboth & 19.2 \\
\hline & Royseux IX & 19.0 \\
\hline & Les Ornais & 20.0 \\
\hline & Sprimont & 31.0 \\
\hline & Rondia & 31.0 \\
\hline & Jenneret & 33.0 \\
\hline & Mercier & 34.0 \\
\hline & Gripierres & 35.0 \\
\hline & Moris & 36.0 \\
\hline & La Préalle & 38.0 \\
\hline & Belle-Roche & 47.0 \\
\hline
\end{tabular}

Appendix 2. Equation and regression curve for the calculation of productivity.

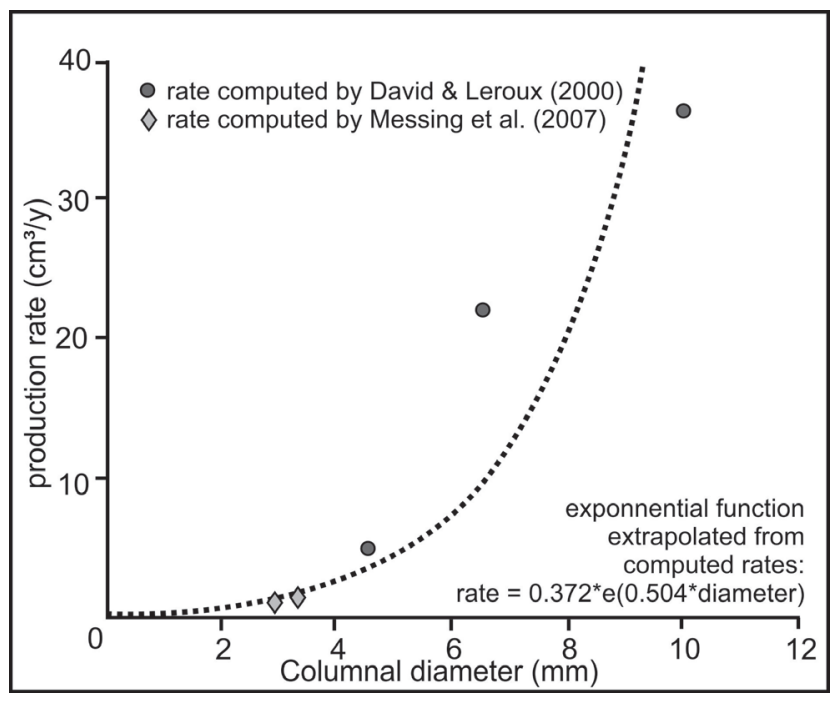

